\title{
Lumbar Interlaminar Epidural Injections in Managing Chronic Low Back and Lower Extremity Pain: A Systematic Review
}

Allan T. Parr, MD1, Sudhir Diwan, $\mathrm{MD}^{2}$, and Salahadin Abdi, MD, PhD³

From: 'Premier Pain Center, Covington, LA; ${ }^{2}$ New York Presbyterian Hospital, Weill Cornell Medical College, New

York, NY; and 3University of Miami, Miller School of Medicine, Miami, FL.

Dr. Parr is Medical Director of Premier Pain Center, Covington, LA.

Dr. Diwan is Director of Pain Medicine in the Department of Anesthesiology, New York Presbyterian Hospital, and the Director of the Tri-Institutional Pain Fellowship Program, Weill Cornell Medical College, New York, NY. Dr. Abdi is Professor and Chief, Division of Pain Medicine, Department of Anesthesiology, Perioperative Medicine and

Pain Management, University of Miami, Miller School of Medicine, Miami, FL.

Address correspondence: Allan T. Parr, MD Medical Director Premier Pain Center 7015 Highway 190, Service Road, Suite 101 Covington, LA 70433 E-mail: alparr@alparr.com

Disclaimer: There was no external funding in the preparation of this manuscript. Conflict of interest: None.

Manuscript received: 11/7/2008 Accepted for publication: $12 / 5 / 2008$

Free full manuscript: www.painphysicianjournal.com
Background: Low back pain with or without lower extremity pain is the most common problem among chronic pain disorders with significant economic, societal, and health impact. Epidural injections are one of the most commonly performed interventions in the United States in managing chronic low back pain. However the evidence is highly variable among different techniques utilized - namely interlaminar, caudal, transforaminal - and for various conditions, namely - intervertebral disc herniation, spinal stenosis, and discogenic pain without disc herniation or radiculitis.

Study Design: A systematic review of lumbar interlaminar epidural injections with or without steroids.

Objective: To evaluate the effect of lumbar interlaminar epidural injections with or without steroids in managing various types of chronic low back and lower extremity pain emanating as a result of disc herniation or radiculitis, spinal stenosis, and chronic discogenic pain.

Methods: Review of the literature and methodologic quality assessment were performed according to the Cochrane Musculoskeletal Review Group Criteria as utilized for interventional techniques for randomized trials and the Agency for Healthcare Research and Quality (AHRQ) criteria for observational studies.

The level of evidence was classified as Level I, II, or III based on the quality of evidence developed by the U.S. Preventive Services Task Force (USPSTF) for therapeutic interventions.

Data sources included relevant literature of the English language identified through searches of PubMed and EMBASE from 1966 to November 2008, and manual searches of bibliographies of known primary and review articles. Results of analysis were performed for multiple conditions separately.

Outcome Measures: The primary outcome measure was pain relief (short-term relief $=$ up to 6 months and long-term $>6$ months). Secondary outcome measures were improvement in functional status, psychological status, return to work, and reduction in opioid intake.

Results: The available literature included only blind epidural injections without fluoroscopy. The indicated evidence is positive (Level II-2) for short-term relief of pain of disc herniation or radiculitis utilizing blind interlaminar epidural steroid injections with lacking of evidence with Level III for long-term relief for disc herniation and radiculitis. The evidence is lacking with Level III for short and long-term relief for spinal stenosis and discogenic pain without radiculitis or disc herniation utilizing blind epidural injections.

Limitations: The limitations of this study include paucity of literature, lack of quality evidence, lack of fluoroscopic procedures, and lack of applicable evidence in contemporary interventional pain management practices.

Conclusion: The evidence based on this systematic review is limited for blind interlaminar epidurals in managing all types of pain except for short-term relief of pain secondary to disc herniation and radiculitis. This evidence does not represent contemporary interventional pain management practices and also the evidence may not be extrapolated to fluoroscopically directed lumbar interlaminar epidural injections.

Key words: Chronic low back pain, lower extremity pain, disc herniation, radiculitis, spinal stenosis, discogenic pain, lumbar interlaminar epidural injections, caudal epidural injections, transforaminal epidural injections, epidural steroids, local anesthetic

Pain Physician 2009: 12:1:163-188 
ow back pain with or without lower extremity pain is the most common problem among chronic pain disorders with significanteconomic, societal, and health impact (1-12). Chronic low back pain is a multifactorial disorder with many possible etiologies. Kuslich et al (13) identified intervertebral discs, facet joints, ligaments, fascia, muscles, and nerve root dura as tissues capable of transmitting pain in the low back. A widespread interest was created in the disc as a source of pain in American literature by Mixter and Barr (14) in 1934 with their hallmark description of the herniated nucleus pulposus. In addition, Mixter and Ayers (15), just one year after the original description in 1934, demonstrated that radicular pain can occur without disc herniation. Subsequently, numerous investigators (16-24) have described pain syndromes emanating from lumbar intervertebral disc without mechanically compressing neural structures. Consequently, the pathophysiology of spinal radicular pain is a subject of ongoing research and controversy and discogenic pain has assumed a major role as a cause of non-specific low back pain, beyond the more specific cause of disc herniation. Thus, in addition to the mechanical component, inflammation of the compressed nerve root is an important factor in the pathophysiology of radicular and discogenic pain $(22,24-31)$. Other proposed etiologies include neural compression with dysfunction and vascular compromise (32-36). Further, neurotoxicity has been attributed to many agents including phospholipase A2 (PLA $)$ and tumor necrosis factor (TNF $\alpha$ ) which may play an essential role in intervertebral disc-induced nerve root damage (18,26-30,37-40).

Intervertebral disc herniation, spinal stenosis, intervertebral disc degeneration without disc herniation, degenerative spondylolisthesis with stenosis, and post lumbar surgery syndrome are the most common diagnoses of low back and leg symptoms (14-21,41-51).

Epidural injections are the most commonly performed interventions in the United States in managing chronic low back pain (52-58). Among several approaches available to access the lumbar epidural space, the lumbar interlaminar approach is the most commonly used, the other 2 being the lumbar transforaminal approach and caudal approach $(1,58,59)$. The interlaminar approach has been touted as its entry can be directed more closely to the assumed site of pathology, requiring less volume than the caudal route and it is less risky compared to the transforaminal approach which is considered to be a more target-spe- cific approach requiring the smallest volume to reach the primary site of pathology.

However, epidural procedures continue to be controversial regarding their effectiveness, indications, and medical necessity $(1,58-73)$. The evidence is highly variable based on the reviewer with ratings ranging from indeterminate to moderate in various publications. The majority of the literature on lumbar interlaminar epidurals appears to be negative. The first systematic review of the effectiveness of epidural steroid injections was performed by Kepes and Duncalf in 1985 (61) which concluded that the rationale for epidural and systemic steroids had not been proven. However, in a follow-up systematic review in 1986, Benzon (73), utilizing the same studies, concluded that mechanical causes of low back pain, especially those accompanied by signs of nerve root irritation, may respond to epidural steroid injections. The differences in the conclusions of Kepes and Duncalf (61) and Benzon (73) may have been due to the fact that Kepes and Duncalf (61) included studies on systematic steroids, whereas Benzon (73) limited his analysis to studies on epidural steroid injections only.

Bogduk et al (59) extensively reviewed caudal, interlaminar, and transforaminal epidural injections, including all of the literature available at that time. They concluded that the results of lumbar interlaminar epidural steroids strongly refute the utility of epidural steroids in acute sciatica. Bogduk (60) updated their recommendations in 1999, recommending against epidural steroids by the lumbar route because effective treatment required too high a number for successful treatment. In 1995, Koes et al (62) reviewed 12 trials of lumbar and caudal epidural steroid injections (combined together) and reported positive results from only 6 studies, concluding that there was no evidence for epidural steroids in managing lumbar radicular pain. Their updated review (63) with 15 trials arrived at similar conclusions that there was no evidence that epidural steroid injections are effective in patients with chronic back pain without sciatica. Overall, the evidence for lumbar interlaminar epidural steroid injections is limited in managing pain secondary to disc herniation. However, available evidence is even inferior in managing axial low back pain and lumbar spinal stenosis $(58,65,66)$.

The underlying mechanism of action of epidurally administered local anesthetic and steroid injections is not well understood. However, multiple hypotheses have been presented indicating pain relief by vari- 
ous mechanisms both by steroids and local anesthetics (74-87). In fact, the effect of local anesthetic with or without steroids has been reported to be the same in epidural injections in clinical studies (88-91), facet joint nerve blocks (78-80), as well as in an experimental evaluation of nerve root infiltration (87).

Due to the ongoing controversy and lack of significant evidence, this systematic review is undertaken to evaluate the effects of lumbar interlaminar epidural injections in managing chronic low back and lower extremity pain secondary to lumbar disc herniation and radiculitis, spinal stenosis, and chronic low back pain of discogenic origin without radiculitis or disc herniation.

\section{Methods}

\section{Literature Search}

A comprehensive literature search was conducted which included the search of databases including PubMed and EMBASE from 1966 through November 2008, Cochrane database, Clinical Trial Registry, systematic reviews, narrative reviews, and cross-references to the reviews published in the English language.

The search strategy emphasized chronic low back pain of discogenic origin with a focus on lumbar epidural injections. Search terminology included lumbar intervertebral disc, disc-related pain, spinal stenosis, and lumbar epidural injections.

\section{Selection Criteria}

The review focused on randomized trials and observational studies, and reports of complications. The population of interest was patients suffering with chronic low back pain for at least 3 months. Only lumbar interlaminar epidural injections with or without steroids were evaluated. All the studies providing appropriate management with outcome evaluations of 6 months or longer and statistical evaluations were reviewed. Reports without appropriate diagnosis, nonsystematic reviews, book chapters, and case reports were excluded.

\section{Outcome Parameters}

The outcome measures were of documented pain relief at various points in time, functional assessment, and other outcomes including psychological improvement, return to work, and change in opioid intake.

\section{Methodologic Quality Assessment}

The quality of each individual article used in this analysis was assessed by modified Cochrane review criteria with weighted scores (Table 1) (62) for randomized trials and the Agency for Healthcare Research and Quality (AHRQ) quality criteria for assessment of observational studies (Table 2) (92) with consensusbased weighted scoring developed by the guidelines committee of the American Society of Interventional Pain Physicians (ASIPP) utilized in multiple evaluations (70,93-97).

Only the studies scoring at least 50 of 100 on weighted scoring criteria were utilized for analysis.

Each study was evaluated by 2 physicians for stated criteria and any disagreements were resolved by a third physician.

If there was a conflict of interest with the reviewed manuscripts with authorship or any other type of conflict, the involved authors did not review the manuscripts for quality assessment or evidence synthesis.

\section{Clinical Relevance}

Clinical relevance of the included studies was evaluated according to 5 questions recommended by the Cochrane Back Review Group (66,98-100).

Table 3 shows the clinical relevance questions. Each question was scored positive (+) if the clinical relevance item was met, negative $(-)$ if the item was not met, and unclear (?) if data were not available to answer the question.

In the recent Cochrane review of "Injection Therapy for Subacute and Chronic Low Back Pain" (66) the authors considered a $20 \%$ improvement in pain scores (98) and a 10\% improvement in functioning outcomes (99) to be clinically important. The current study utilized stricter criteria than general systematic reviews and previous systematic reviews. Any relief of 6 months or less was considered as short-term, whereas Cochrane reviews (66) and others have considered 6 weeks as short-term and longer than 6 weeks as long-term. We also utilized methodologic quality assessment criteria (66) for minimum inclusion, thus this systematic review is expected to provide robust results with stricter criteria. However, in contrast to many other systematic reviews, we have not excluded observational studies and included only quality observational studies with scores of 50 or more on a scale of 0-100 based on AHRQ criteria. This improves the generalizability of the systematic review and the intervention. However, in interventional pain management settings, significant improvement has been defined as $50 \%$ or more relief, whereas significant improve- 
Table 1. Modified and weighted Cochrane methodologic quality assessment criteria.

\begin{tabular}{|c|c|c|}
\hline & CRITERION & $\begin{array}{c}\text { Weighted } \\
\text { Score (points) }\end{array}$ \\
\hline & population & 35 \\
\hline A & Homogeneity & 2 \\
\hline B & Comparability of relevant baseline characteristics & 5 \\
\hline $\mathrm{C}$ & Randomization procedure adequate & 4 \\
\hline $\mathrm{D}$ & Drop-outs described for each study group separately & 3 \\
\hline $\mathrm{E}$ & $<20 \%$ loss for follow-up & 2 \\
\hline & $<10 \%$ loss for follow-up & 2 \\
\hline $\mathrm{F}$ & $>50$ subject in the smallest group & 8 \\
\hline & $>100$ subjects in the smallest group & 9 \\
\hline & entions & 25 \\
\hline G & Interventions included in protocol and described & 10 \\
\hline $\mathrm{H}$ & Pragmatic study & 5 \\
\hline I & Co-interventions avoided or similar & 5 \\
\hline $\mathrm{J}$ & Placebo-controlled & 5 \\
\hline & & 30 \\
\hline $\mathrm{K}$ & Patients blinded & 5 \\
\hline $\mathrm{L}$ & Outcome measures relevant & 10 \\
\hline M & Blinded outcome assessments & 10 \\
\hline $\mathrm{N}$ & Follow-up period adequate & 5 \\
\hline & presentation and analysis & 10 \\
\hline $\mathrm{O}$ & Intention-to-treat analysis & 5 \\
\hline $\mathrm{P}$ & Frequencies of most important outcomes presented for each treatment group & 5 \\
\hline & TOTAL SCORE & 100 \\
\hline
\end{tabular}

Adapted from Koes BW et al. Efficacy of epidural steroid injections for low-back pain and sciatica: A systematic review of randomized clinical trials. Pain 1995; 63:279-288 (62).

ment in disability has been defined as a $40 \%$ or more decrease in disability scores in multiple publications (78-80,88-91,101-104).

\section{Analysis of Evidence}

Quality analysis was conducted using 5 levels of evidence, ranging from Level I to III with 3 subcategories in Level II, as illustrated in Table 4 (105).

Grading recommendations were based on Guyatt et al's criteria as illustrated in Table 5 (106).

\section{Outcome of the Studies}

A study is judged to be positive if the epidural injection therapy was effective, either with a placebo control or active control in randomized trials. This indicates that the difference in the effect for the prima- ry outcome measure was statistically significant at the conventional $5 \%$ level. In a negative study, no difference was reported between the study treatments or no improvement from baseline. Further, the outcomes were judged at the reference point with positive or negative results reported at 3 months, 6 months, and one year.

For observational studies, a study was judged to be positive if the epidural injection therapy was effective, with outcomes reported at the reference point with positive or negative results at 3 months, 6 months, and one year. Relief of 6 months or less was considered as short-term and relief of longer than 6 months was considered as long-term.

The data will be analyzed separately for disc herniation and/or radiculopathy, discogenic pain with 
Table 2. Modified AHRQ quality assessment criteria for observational studies.

\begin{tabular}{|c|c|}
\hline CRITERION & Weighted Score (points) \\
\hline 1. Study Question & 2 \\
\hline \multicolumn{2}{|l|}{ - Clearly focused and appropriate question } \\
\hline 2. Study Population & 8 \\
\hline - Description of study population & 5 \\
\hline - Sample size justification & 3 \\
\hline 3. Comparability of Subjects & 22 \\
\hline - Specific inclusion/exclusion criteria for all groups & 5 \\
\hline - Criteria applied equally to all groups & 3 \\
\hline - Comparability of groups at baseline with regard to disease status and prognostic factors & 3 \\
\hline - Study groups comparable to non-participants with regard to confounding factors & 3 \\
\hline - Use of concurrent controls & 5 \\
\hline - Comparability of follow-up among groups at each assessment & 3 \\
\hline 4. Exposure or Intervention & 11 \\
\hline - Clear definition of exposure & 5 \\
\hline - Measurement method standard, valid and reliable & 3 \\
\hline - Exposure measured equally in all study groups & 3 \\
\hline 5. Outcome measures & 20 \\
\hline - Primary/secondary outcomes clearly defined & 5 \\
\hline - Outcomes assessed blind to exposure or intervention & 5 \\
\hline - Method of outcome assessment standard, valid and reliable & 5 \\
\hline - Length of follow-up adequate for question & 5 \\
\hline 6. Statistical Analysis & 19 \\
\hline - Statistical tests appropriate & 5 \\
\hline - Multiple comparisons taken into consideration & 3 \\
\hline - Modeling and multivariate techniques appropriate & 2 \\
\hline - Power calculation provided & 2 \\
\hline - Assessment of confounding & 5 \\
\hline - Dose-response assessment if appropriate & 2 \\
\hline 7. Results & 8 \\
\hline - Measure of effect for outcomes and appropriate measure of precision & 5 \\
\hline - Adequacy of follow-up for each study group & 3 \\
\hline 8. Discussion & 5 \\
\hline \multicolumn{2}{|l|}{ - Conclusions supported by results with possible biases and limitations taken into consideration } \\
\hline 9. Funding or Sponsorship & 5 \\
\hline \multicolumn{2}{|l|}{ - Type and sources of support for study } \\
\hline TOTAL SCORE & 100 \\
\hline
\end{tabular}

Adapted and modified from West S et al. Systems to Rate the Strength of Scientific Evidence, Evidence Report, Technology Assessment No. 47. AHRQ Publication No. 02-E016 (92).

Table 3. Clinical relevance questions.

\begin{tabular}{|ll||}
\hline A) & Are the patients described in detail so that you can decide whether they are comparable to those that you see in your practice? \\
\hline B) & Are the interventions and treatment settings described well enough so that you can provide the same for your patients? \\
\hline C) & Were all clinically relevant outcomes measured and reported? \\
\hline D) & Is the size of the effect clinically important? \\
\hline E) & Are the likely treatment benefits worth the potential harms? \\
\hline
\end{tabular}

Source: Staal JB et al. Injection therapy for subacute and chronic low-back pain. Cochrane Database Syst Rev 2008; 3:CD001824 (66). 
Table 4. Quality of evidence developed by USPSTF.

\begin{tabular}{|c|l||}
\hline I: & Evidence obtained from at least one properly randomized controlled trial \\
\hline II-1: & Evidence obtained from well-designed controlled trials without randomization \\
\hline II-2: & $\begin{array}{l}\text { Evidence obtained from well-designed cohort or case-control analytic studies, preferably from more than one } \\
\text { center or research group }\end{array}$ \\
\hline II-3: & $\begin{array}{l}\text { Evidence obtained from multiple time series with or without the intervention. Dramatic results in uncontrolled } \\
\text { experiments (such as the results of the introduction of penicillin treatment in the 1940s) could also be regarded } \\
\text { as this type of evidence }\end{array}$ \\
\hline III: & $\begin{array}{l}\text { Opinions of respected authorities, based on clinical experience descriptive studies and case reports or reports of } \\
\text { expert committees }\end{array}$ \\
\hline
\end{tabular}

Adapted from the U.S. Preventive Services Task Force (USPSTF) (105).

Table 5. Grading recommendations.

\begin{tabular}{|c|c|c|c|}
\hline $\begin{array}{l}\text { Grade of Recommendation/ } \\
\text { Description }\end{array}$ & $\begin{array}{l}\text { Benefit vs Risk and } \\
\text { Burdens }\end{array}$ & $\begin{array}{l}\text { Methodological Quality of } \\
\text { Supporting Evidence }\end{array}$ & Implications \\
\hline $\begin{array}{l}1 \mathrm{~A} / \text { strong recommendation, high- } \\
\text { quality evidence }\end{array}$ & $\begin{array}{l}\text { Benefits clearly outweigh } \\
\text { risk and burdens, or vice } \\
\text { versa }\end{array}$ & $\begin{array}{l}\text { RCTs without important limitations } \\
\text { or overwhelming evidence from } \\
\text { observational studies }\end{array}$ & $\begin{array}{l}\text { Strong recommendation, } \\
\text { can apply to most patients in } \\
\text { most circumstances without } \\
\text { reservation }\end{array}$ \\
\hline $\begin{array}{l}1 \mathrm{~B} / \text { strong recommendation, moder- } \\
\text { ate quality evidence }\end{array}$ & $\begin{array}{l}\text { Benefits clearly outweigh } \\
\text { risk and burdens, or vice } \\
\text { versa }\end{array}$ & $\begin{array}{l}\text { RCTs with important limitations } \\
\text { (inconsistent results, methodologi- } \\
\text { cal flaws, indirect, or imprecise) or } \\
\text { exceptionally strong evidence from } \\
\text { observational studies }\end{array}$ & $\begin{array}{l}\text { Strong recommendation, } \\
\text { can apply to most patients in } \\
\text { most circumstances without } \\
\text { reservation }\end{array}$ \\
\hline $\begin{array}{l}1 \mathrm{C} / \text { strong recommendation, low- } \\
\text { quality or very low-quality evidence }\end{array}$ & $\begin{array}{l}\text { Benefits clearly outweigh } \\
\text { risk and burdens, or vice } \\
\text { versa }\end{array}$ & Observational studies or case series & $\begin{array}{l}\text { Strong recommendation but } \\
\text { may change when higher qual- } \\
\text { ity evidence becomes available }\end{array}$ \\
\hline $\begin{array}{l}\text { 2A/weak recommendation, high- } \\
\text { quality evidence }\end{array}$ & $\begin{array}{l}\text { Benefits closely balanced } \\
\text { with risks and burden }\end{array}$ & $\begin{array}{l}\text { RCTs without important limitations } \\
\text { or overwhelming evidence from } \\
\text { observational studies }\end{array}$ & $\begin{array}{l}\text { Weak recommendation, best } \\
\text { action may differ depending } \\
\text { on circumstances or patients' } \\
\text { or societal values }\end{array}$ \\
\hline $\begin{array}{l}2 \mathrm{~B} / \text { weak recommendation, moderate- } \\
\text { quality evidence }\end{array}$ & $\begin{array}{l}\text { Benefits closely balanced } \\
\text { with risks and burden }\end{array}$ & $\begin{array}{l}\text { RCTs with important limitations } \\
\text { (inconsistent results, methodologi- } \\
\text { cal flaws, indirect, or imprecise) or } \\
\text { exceptionally strong evidence from } \\
\text { observational studies }\end{array}$ & $\begin{array}{l}\text { Weak recommendation, best } \\
\text { action may differ depending } \\
\text { on circumstances or patients' } \\
\text { or societal values }\end{array}$ \\
\hline $\begin{array}{l}2 \mathrm{C} / \text { weak recommendation, low-qual- } \\
\text { ity or very low-quality evidence }\end{array}$ & $\begin{array}{l}\text { Uncertainty in the esti- } \\
\text { mates of benefits, risks, } \\
\text { and burden; benefits, risk, } \\
\text { and burden may be closely } \\
\text { balanced }\end{array}$ & Observational studies or case series & $\begin{array}{l}\text { Very weak recommendations; } \\
\text { other alternatives may be } \\
\text { equally reasonable }\end{array}$ \\
\hline
\end{tabular}

Adapted from Guyatt G et al. Grading strength of recommendations and quality of evidence in clinical guidelines. Report from an American College of Chest Physicians task force. Chest 2006; 129:174-181 (106). 
predominantly low back pain, and spinal stenosis.

Studies performed under fluoroscopy were given priority.

Observational studies were only included in the evidence synthesis if there were less than 4 randomized trials meeting inclusion criteria for each category as described above. If a study included more than one type of patient and the analysis in the study was considered separately for both conditions, that study was included for all the conditions.

\section{Results}

A literature search was carried out for lumbar interlaminar epidural injections as shown in Fig. 1.

Our search strategy yielded multiple studies evaluating the effectiveness of interlaminar epidural injections with or without steroids. These included 20 randomized or double-blind trials (107-126) and 30 observational studies (127-156).

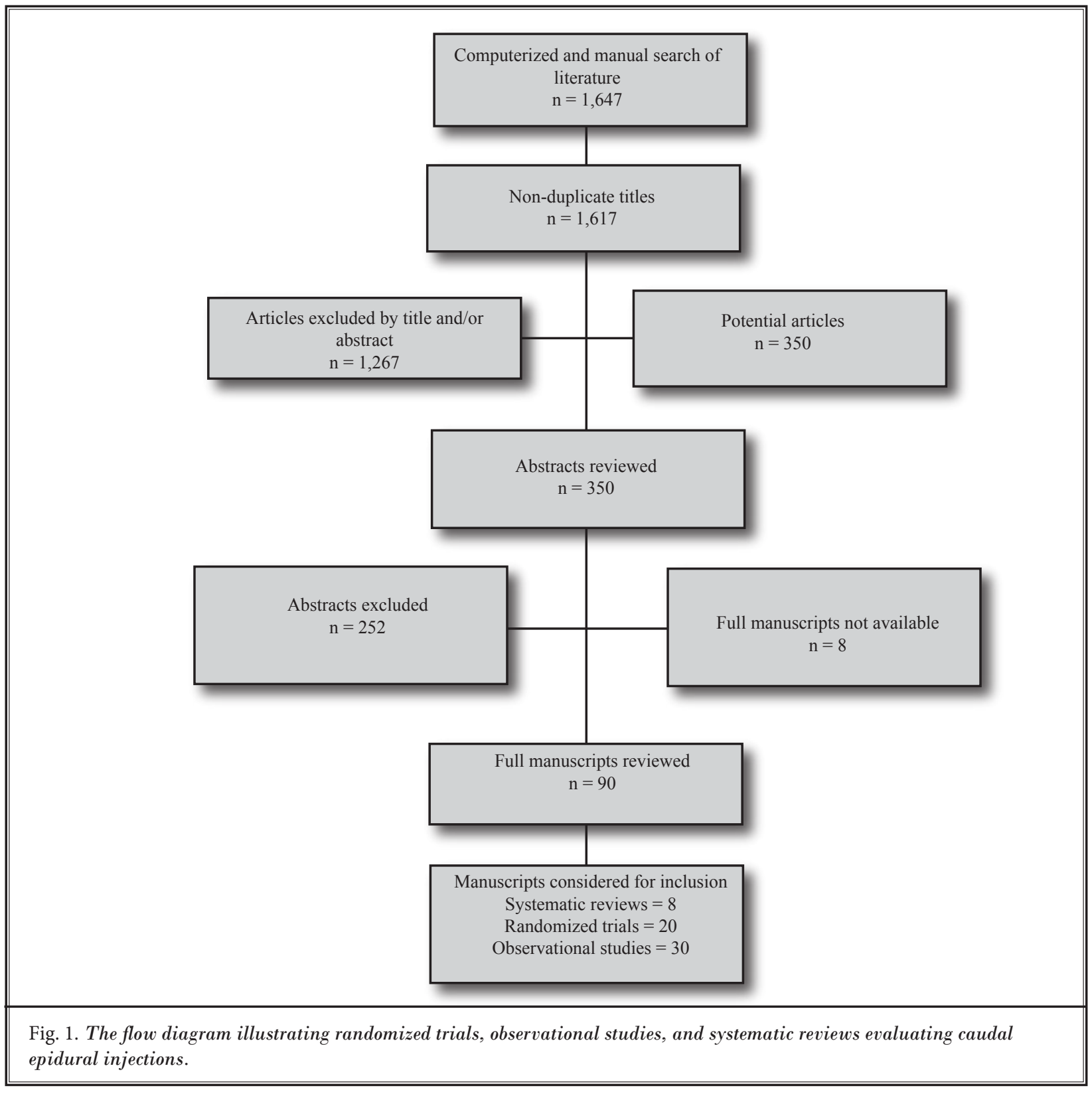




\section{Randomized Trials}

\section{Methodologic Quality Assessment}

Of the 20 randomized trials, 11 studies met inclusion criteria $(107-111,115,116,122,123,125,126)$. Of these, 6 studies met the inclusion criteria to be included for methodological assessment $(108-110,115,125,126)$. Reasons for exclusion were as follows:

- Serrao et al (112) was excluded as they studied the effects of subarachnoid and epidural midazolam.

- Two studies $(117,118)$ were excluded since they focused on diabetic polyneuropathy and intractable post-herpetic neuralgia.

- Buchner et al (120) was excluded as they evaluated only inpatients.

- Multiple evaluations $(107,111,113,114,116,121$ 124) were excluded for lack of evaluation of longterm outcomes.

Methodological quality criteria are illustrated in Table 6 showing all the randomized clinical trials evaluating the effectiveness of lumbar interlaminar epidural injections. The quality assessment criteria

Table 6. Methodological assessment of randomized trials evaluating the effectiveness of lumbar interlaminar epidural injections.

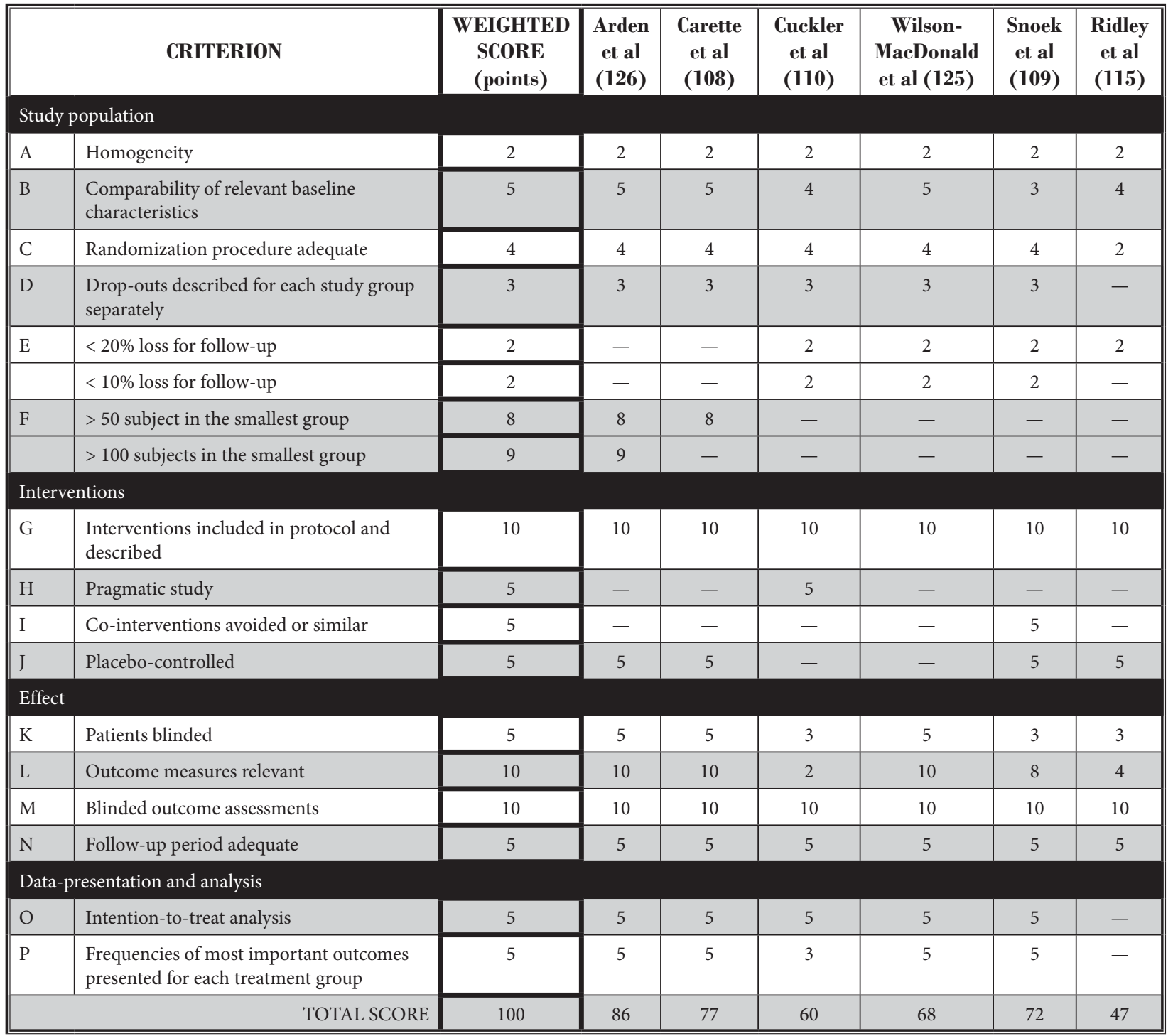

Methodological criteria and scoring adapted from Koes BW et al. Efficacy of epidural steroid injections for low-back pain and sciatica: A systematic review of randomized clinical trials. Pain 1995; 63:279-288 (62). 
ranged from 47 to 86 with 5 of 6 trials meeting inclusion criteria.

\section{Clinical Relevance Assessment}

Table 7 illustrates the clinical relevance of randomized trials. The scores were 3 of 5 for all the trials.

\section{Inclusion Criteria}

Of the 5 studies meeting inclusion criteria for evidence synthesis, 4 of them $(108,109,125,126)$ included patients with disc herniation and sciatica, whereas one study (110) included patients with acute herniated nucleus pulposus or spinal stenosis of longer than 6 months.

There were no randomized trials evaluating the patients either with spinal stenosis alone or with chronic low back pain of discogenic origin without radiculitis.

\section{Observational Studies}

Of the 30 observational studies (127-156), 2 studies were excluded as they were not related to the lumbar interlaminar procedure $(139,146)$. One study was excluded due to factor analysis rather than outcome assessment (138). Five studies were excluded due to short-term follow up $(129,141,143,149,155)$. One study $(131)$ was excluded due to short-term relief and the procedure was being performed in an inpatient setting. Seven studies were excluded due to non-availability of full manuscripts or data for methodology quality assessment $(127,130,132,133,144,153,154)$.

\section{Methodologic Quality Assessment}

Methodologic quality assessment was performed on the studies evaluating either spinal stenosis or discogenic pain. No observational studies were included for disc herniation or radiculitis as 6 randomized trials $(108-110,115,125,136)$ met inclusion criteria.

Among the observational studies meeting the inclusion criteria for evidence synthesis, one evaluation studied chronic discogenic low back pain without radiculitis (148) and one study evaluated spinal stenosis (150). Of all the studies meeting inclusion criteria, only one study by Butterman (148) was performed under fluoroscopy. There was only one study meeting inclusion criteria evaluating the role of epidural steroid injections in spinal stenosis.

Methodologic quality assessment criteria are illustrated in Table 8. Butterman (148) scored 75, whereas Campbell et al (150) scored 53, thus both of them met inclusion criteria.

\section{Disc Herniation and Radiculitis}

Of the studies meeting inclusion criteria (108$110,126,127)$, Cuckler et al (110) studied patients with either acute herniated nucleus pulposus or spinal stenosis of greater than 6 months. Of the 73 patients with back pain included in the study, 34 were secondary to acute herniated nucleus pulposus, whereas 37 patients were secondary to spinal stenosis reducing the sample size (110). Wilson-MacDonald et al (125) included 32 patients with spinal stenosis, with 43 patients with disc herniation. All other studies evaluated the role of epidural injections in sciatica or radiculitis.

Table 7. Assessment of clinical relevance of randomized clinical trials evaluating the effectiveness of lumbar interlaminar epidural injections.

\begin{tabular}{|l|c|c|c|c|c|}
\hline & $\begin{array}{c}\text { Arden et } \\
\text { al (126) }\end{array}$ & $\begin{array}{c}\text { Carette et } \\
\text { al (108) }\end{array}$ & $\begin{array}{c}\text { Cuckler et } \\
\text { al (110) }\end{array}$ & $\begin{array}{c}\text { Wilson- } \\
\text { MacDonald } \\
\text { (125) }\end{array}$ & $\begin{array}{c}\text { Snoek et } \\
\text { al (109) }\end{array}$ \\
\hline $\begin{array}{l}\text { A) «Are the patients described in detail so that you can decide } \\
\text { whether they are comparable to those that you see in your practice? }\end{array}$ & + & + & + & + & + \\
\hline $\begin{array}{l}\text { B) «Are the interventions and treatment settings described well } \\
\text { enough so that you can provide the same for your patients? }\end{array}$ & - & - & - & - & - \\
\hline C) «Were all clinically relevant outcomes measured and reported? & + & + & + & + & + \\
\hline D) «Is the size of the effect clinically important? & + & + & + & + & + \\
\hline E) «Are the likely treatment benefits worth the potential harms? & - & - & - & - & - \\
\hline TOTAL CRITERIA MET & $3 / 5$ & $3 / 5$ & $3 / 5$ & $3 / 5$ & $3 / 5$ \\
\hline
\end{tabular}

$+=$ positive; $-=$ negative; $?=$ unclear

Scoring adapted from Staal JB et al. Injection therapy for subacute and chronic low-back pain. Cochrane Database Syst Rev 2008; 3:CD001824 (66). 
Table 8. Methodological assessment of observational studies evaluating the effectiveness of lumbar interlaminar epidural injections.

\begin{tabular}{|c|c|c|c|}
\hline CRITERION & $\begin{array}{c}\text { Weighted } \\
\text { Score } \\
\text { (points) }\end{array}$ & $\begin{array}{c}\text { Butterman } \\
\text { (148)* }\end{array}$ & $\begin{array}{c}\text { Campbell et } \\
\text { al (150) }\end{array}$ \\
\hline 1. Study Question & 2 & 2 & 2 \\
\hline - Clearly focused and appropriate question & & 2 & 2 \\
\hline 2. Study Population & 8 & 5 & 5 \\
\hline - Description of study population & 5 & 5 & 5 \\
\hline - Sample size justification & 3 & -- & -- \\
\hline 3. Comparability of Subjects for All Observational Studies & 22 & 14 & 5 \\
\hline - Specific inclusion/exclusion criteria for all groups & 5 & 5 & 5 \\
\hline - Criteria applied equally to all groups & 3 & 3 & -- \\
\hline - Comparability of groups at baseline with regard to disease status and prognostic factors & 3 & 3 & -- \\
\hline - Study groups comparable to non-participants with regard to confounding factors & 3 & -- & -- \\
\hline - Use of concurrent controls & 5 & -- & -- \\
\hline - Comparability of follow-up among groups at each assessment & 3 & 3 & -- \\
\hline 4. Exposure or Intervention & 11 & 11 & 6 \\
\hline - Clear definition of exposure & 5 & 5 & 5 \\
\hline - Measurement method standard, valid and reliable & 3 & 3 & 1 \\
\hline - Exposure measured equally in all study groups & 3 & 3 & -- \\
\hline 5. Outcome measures & 20 & 15 & 10 \\
\hline - Primary/secondary outcomes clearly defined & 5 & 5 & 5 \\
\hline - Outcomes assessed blind to exposure or intervention & 5 & -- & -- \\
\hline - Method of outcome assessment standard, valid and reliable & 5 & 5 & -- \\
\hline 6. Statistical Analysis & 19 & 10 & 10 \\
\hline - Statistical tests appropriate & 5 & 5 & 5 \\
\hline - Multiple comparisons taken into consideration & 3 & 3 & 3 \\
\hline - Modeling and multivariate techniques appropriate & 2 & 2 & 2 \\
\hline - Power calculation provided & 2 & -- & -- \\
\hline - Assessment of confounding & 5 & -- & -- \\
\hline - Dose-response assessment if appropriate & 2 & -- & -- \\
\hline 7. Results & 8 & 8 & 5 \\
\hline - Measure of effect for outcomes and appropriate measure of precision & 5 & 5 & 2 \\
\hline - Adequacy of follow-up for each study group & 3 & 3 & 3 \\
\hline 8. Discussion & 5 & 5 & 5 \\
\hline $\begin{array}{l}\text { - Conclusions supported by results with possible biases and limitations taken into } \\
\text { consideration }\end{array}$ & & 5 & 5 \\
\hline 9. Funding or Sponsorship & 5 & 5 & 5 \\
\hline - Type and sources of support for study & & 5 & 5 \\
\hline TOTAL SCORE & 100 & 75 & 53 \\
\hline
\end{tabular}

${ }^{\star}$ Performed utilizing fluoroscopy

Adapted and modified from West S et al. Systems to Rate the Strength of Scientific Evidence, Evidence Report, Technology Assessment No. 47. AHRQ Publication No. 02-E016 (92). 


\section{Study Characteristics}

Table 9 shows the characteristics of randomized trials of lumbar interlaminar epidural injections evaluating disc herniation and radiculitis. Surprisingly, none of the studies were performed under fluoroscopy.
Cuckler et al (110) performed a prospective, randomized, double-blind study of the use of epidural steroids in the treatment of lumbar radicular pain. They included 73 patients with a clinical diagnosis of either acute herniated nucleus pulposus or spinal stenosis

Table 9. Characteristics of published randomized trials of blind lumbar interlaminar epidural injections in managing disc herniation and radiculitis.

\begin{tabular}{|c|c|c|c|c|c|}
\hline Study/Methods & Participants & Intervention(s) & Outcome(s) & Result(s) & $\begin{array}{l}\text { Conclusion }(\mathrm{s}) \\
\text { Short-term } \\
\text { relief } \leq 6 \mathrm{mos} \text {. } \\
\text { Long-term } \\
\text { relief }>6 \text { mos. }\end{array}$ \\
\hline $\begin{array}{l}\text { Wilson-Mac- } \\
\text { Donald et al } \\
2005 \text { (125) } \\
\text { Randomized, } \\
\text { controlled } \\
\text { trial }\end{array}$ & $\begin{array}{l}93 \text { pts. with MRI evidence of a } \\
\text { disc prolapse, spinal stenosis, or } \\
\text { a combination. } \\
\text { Pts. had lumbosacral nerve root } \\
\text { pain which had not resolved } \\
\text { within } 6 \text { wks minimum. } \\
32 \text { pts. with } 18 \text { into the epidural } \\
\text { group and } 14 \text { in the control group } \\
\text { had spinal stenosis only, whereas } \\
3 \text { pts. in the epidural group and } \\
15 \text { pts. in control group had a } \\
\text { combined disc herniation and } \\
\text { spinal stenosis. }\end{array}$ & $\begin{array}{l}\text { Experimental: } \\
\text { epidural injection of } \\
\text { bupivacaine } 0.5 \% \text { ( } 40 \\
\mathrm{mg} \text { ) with methyl- } \\
\text { prednisolone } 80 \mathrm{mg} \text {. } \\
\text { Control: intramuscu- } \\
\text { lar injection of } 0.5 \% \\
(40 \mathrm{mg} \text { ) bupiva- } \\
\text { caine with } 80 \mathrm{mg} \\
\text { methylprednisolone. }\end{array}$ & $\begin{array}{l}\text { Timing: } 6 \text { wks, } 24 \\
\text { mos. } \\
\text { Outcome measures: } \\
\text { Oswestry Disability } \\
\text { index, pain relief. }\end{array}$ & $\begin{array}{l}\text { In the first } 5 \text { wks } \\
\text { after epidural } \\
\text { injection a useful } \\
\text { improvement in } \\
\text { nerve root symp- } \\
\text { toms was seen. }\end{array}$ & $\begin{array}{l}\text { Positive short-term } \\
\text { and negative long- } \\
\text { term relief }\end{array}$ \\
\hline $\begin{array}{l}\text { Arden et al } 2005 \\
(126) \\
\text { Double-blind, } \\
\text { randomized } \\
\text { placebo con- } \\
\text { trolled: TRIM }\end{array}$ & 228 pts. with unilateral sciatica. & $\begin{array}{l}\text { Experimental: } \\
\text { triamcinolone } 80 \mathrm{mg} \\
\text { and } 10 \mathrm{~mL} \text { of } 0.25 \% \\
\text { bupivacaine. } \\
\text { Control: interspinous } \\
\text { injection with } 2 \mathrm{~mL} \text { of } \\
\text { normal saline. }\end{array}$ & $\begin{array}{l}\text { Timing: } 3,6,12,26 \text {, } \\
\text { and } 52 \text { weeks. } \\
\text { Outcome measures: } \\
\text { Oswestry disability } \\
\text { index, Likert scale, } \\
\text { SF-36, VAS. }\end{array}$ & $\begin{array}{l}\text { Lumbar epidural } \\
\text { steroid injection } \\
\text { produced a statisti- } \\
\text { cally significant } \\
\text { improvement in } \\
\text { function over pla- } \\
\text { cebo in } 3 \text { wks. By } 6 \\
\text { wks, benefit lost. }\end{array}$ & $\begin{array}{l}\text { Negative short- and } \\
\text { long-term relief }\end{array}$ \\
\hline $\begin{array}{l}\text { Carette et al } 1997 \\
(108) \\
\text { Randomized, } \\
\text { double-blind } \\
\text { trial }\end{array}$ & $\begin{array}{l}158 \text { pts. with sciatica due to a } \\
\text { herniated nucleus pulposus. } \\
\text { Treatment group: } 78 \\
\text { Placebo group: } 80\end{array}$ & $\begin{array}{l}\text { Experimental: meth- } \\
\text { ylprednisolone acetate } \\
\text { ( } 80 \mathrm{mg} \text { and } 8 \mathrm{~mL} \text { of } \\
\text { isotonic saline) } \\
\text { Control: isotonic } \\
\text { saline } 1 \mathrm{~mL} \\
\text { Frequency: } 3 \text { epidural } \\
\text { injections } 3 \text { wks. apart. }\end{array}$ & $\begin{array}{l}\text { Timing: } 6 \text { wks., } 3 \\
\text { mos., } 12 \text { mos. } \\
\text { Outcome measures: } \\
\text { need for surgery, } \\
\text { Oswestry Disability } \\
\text { scores. }\end{array}$ & $\begin{array}{l}\text { Significant } \\
\text { improvement was } \\
\text { seen in leg pain in } \\
\text { the methylpred- } \\
\text { nisolone group } \\
\text { after } 6 \text { weeks, with } \\
\text { no difference after } \\
3 \text { and } 12 \text { mos. }\end{array}$ & $\begin{array}{l}\text { Positive short-term } \\
\text { and negative long- } \\
\text { term relief }\end{array}$ \\
\hline $\begin{array}{l}\text { Cuckler et al } \\
1985 \text { (110) } \\
\text { Randomized, } \\
\text { double-blind } \\
\text { trial }\end{array}$ & $\begin{array}{l}73 \text { pts. with back pain due to } \\
\text { either acute herniated nucleus } \\
\text { pulposus or spinal stenosis of }>6 \\
\text { mos. Experimental: } 42 \text { Control: } \\
3.1\end{array}$ & $\begin{array}{l}\text { Experimental: } 80 \mathrm{mg} \\
(2 \mathrm{~mL}) \text { of methylpred- } \\
\text { nisolone }+5 \mathrm{~mL} \text { of } \\
\text { procaine } 1 \% . \\
\text { Control group: } 2 \\
\mathrm{~mL} \text { saline }+5 \mathrm{~mL} \text { of } \\
\text { procaine } 1 \% .\end{array}$ & $\begin{array}{l}\text { Timing: } 24 \text { hrs and } \\
\text { an average of } 20 \\
\text { mos. } \\
\text { Outcome measures: } \\
\text { subjective improve- } \\
\text { ment, need for } \\
\text { surgery. }\end{array}$ & $\begin{array}{l}\text { There was no } \\
\text { significant short- } \\
\text { term or long-term } \\
\text { improvements } \\
\text { between both } \\
\text { groups. }\end{array}$ & $\begin{array}{l}\text { Negative short-term } \\
\text { and long-term relief }\end{array}$ \\
\hline $\begin{array}{l}\text { Snoek et al } 1977 \\
(109) \\
\text { Randomized trial }\end{array}$ & $\begin{array}{l}51 \text { pts. with lumbar root } \\
\text { compression documented by } \\
\text { neurological deficit and a con- } \\
\text { cordant abnormality noted on } \\
\text { myelography. } \\
\text { Experimental: } 27 \text { Control: } 24\end{array}$ & $\begin{array}{l}\text { Experimental: } 80 \mathrm{mg} \\
\text { of methylprednisolone } \\
(2 \mathrm{~mL}) \text {. } \\
\text { Control: } 2 \mathrm{~mL} \text { of } \\
\text { normal saline } \\
\text { Frequency: single } \\
\text { injection. }\end{array}$ & $\begin{array}{l}\text { Timing: } 3 \text { days and } \\
\text { an average of } 14 \\
\text { mos. } \\
\text { Outcome measures: } \\
\text { Pain, sciatic nerve } \\
\text { stretch tolerance. }\end{array}$ & $\begin{array}{l}\text { No statistically } \\
\text { significant differ- } \\
\text { ences were noted } \\
\text { in either group. }\end{array}$ & $\begin{array}{l}\text { Negative short-term } \\
\text { and long-term relief }\end{array}$ \\
\hline
\end{tabular}


between November 1978 and 1980. All the procedures were performed without fluoroscopy. Ninety percent of the epidural injections were performed by a single anesthesiologist in a lateral decubitus position, between the third and fourth lumbar vertebra, lying on the side of the painful limb. Either $2 \mathrm{~mL}$ of sterile water containing $80 \mathrm{mg}$ of methylprednisolone acetate combined with $5 \mathrm{~mL}$ of $1 \%$ procaine or $2 \mathrm{~mL}$ of saline combined with $5 \mathrm{~mL}$ of $1 \%$ procaine was injected. The authors stated that neither the treating physician, nor the patient was informed of the contents of the initial injection until July 1981; however, they have not described the concealment process. They also provided a second injection if there had been less than $50 \%$ improvement 24 hours after the first injection with methylprednisolone acetate and procaine in a non-blind fashion. Further, they defined a short-term successful result as subject to improvement of $75 \%$ or more as judged by the patient 24 hours after injection. Anything less than $75 \%$ was considered as short-term failure. Further, they described all patients who received a second injection as having a failed result. They also defined any patient who had laminectomy during the period of follow-up (which was over 20 months) as a long-term failed result. They did not provide any special exercise program or other physical therapy. The long-term results showed $25(61 \%)$ of 41 patients who received an epidural steroid injection as the first injection reported some degree of improvement, while 20 $(62.5 \%)$ of the 32 patients who received placebo injection reported some degree of improvement.

These authors utilized a flawed process by considering local anesthetic injection as a placebo. Consequently, this is not an efficacy trial, but it is an equivalency or non-inferiority trial (78-80,88-91). Further, the effectiveness of local anesthetics has been demonstrated and shown to be equal to steroids, both in clinical and experimental studies (78-80,87-91,157162). Further, when multiple variables are considered, the procedure was performed with a blind technique between L3 and L4 in the lateral decubitus position with the affected side down with inability to reach the targeted area in almost half of the patients $(147,163-$ 171). Other flaws of this study include small sample size, poor methodology, and inadequate outcome assessments. Statistically detailed data were not provided to calculate the patients receiving greater than $50 \%$ relief at any point in the evaluation. Further, evaluation was performed only at 2 points. Thus, the results of this study may not provide any value in contemporary interventional pain management.

Carette et al's (108) study has been described as the best study evaluating the role of epidural steroids in managing sciatica due to herniated nucleus pulposus. However, this study also contains numerous deficiencies. Between October 1992 and January 1996, they enrolled 158 patients with 78 patients in the methylprednisolone group and 80 patients in the placebo group. The patients received injections of either 80 $\mathrm{mg}(2 \mathrm{~mL})$ of methylprednisolone acetate mixed with $8 \mathrm{~mL}$ of isotonic saline) or $1 \mathrm{~mL}$ of isotonic saline in the epidural space according to the technique described by Barry and Kendall (172), without fluoroscopy, in a physiatric practice, dating back to 1962 . The procedure was performed without fluoroscopy in the lateral decubitus position and isotonic saline was administered, in fact, into the epidural space. No information is available with regards to the effect of injection of an inert substance into the epidural space. Further, the disadvantages of the spread of the drug, level of the injection, lack of ventral placement of the drug, and lack of fluoroscopy fail to generalize the results to contemporary interventional pain management practice. The results showed that at 3 weeks, the Oswestry Disability Index (ODI) score had improved slightly better in the methylprednisolone group compared to the placebo group, along with significant differences noted with finger-to-floor distance $(P=0.006)$ and sensory deficits $(P=0.003)$, which were greater in the methylprednisolone group. However, after 6 weeks, the only significant difference was the improvement in leg pain, which was greater in the methylprednisolone group $(P=0.03)$. After 3 months, there were no significant differences between the groups. Further, at 12 months, the cumulative probability of back surgery was $25.8 \%$ in the methylprednisolone group and $24.8 \%$ in the placebo group. The authors concluded that even though epidural injections of methylprednisolone may afford short-term improvement in leg pain and sensory deficits in patients with sciatica due to a herniated nucleus pulposus, this treatment offers no significant functional benefit, nor does it reduce the need for surgery compared to saline epidural injection. However two-thirds of the patients in both groups avoided surgery.

Arden et al (126) in a study published in 2005 evaluated the effectiveness and predictors of response to lumbar epidural corticosteroid injections 
in patients with sciatica, in a 12-month, multi-center, double-blind, randomized, placebo-controlled, parallel-group trial in 4 secondary pain-care clinics in the Wessex Region of the United Kingdom. They recruited 228 patients, aged 18 to 70 years, presenting to orthopaedic, rheumatology, and pain clinics at the participating hospitals with a clinical diagnosis of unilateral sciatica between 4 weeks and 18 months duration. Of these, one-third of the patients were acute and twothirds were chronic. All the injections were performed by anesthetists experienced in the procedure. The details of the procedure are not provided, hence, it is assumed they were performed blindly without fluoroscopy and in the lateral position between L3-4 or L4-5. The active group received epidural steroids via the lumbar route of $80 \mathrm{mg}$ of triamcinolone acetonide and $10 \mathrm{~mL}$ of $0.25 \%$ bupivacaine at weeks 0,3 , and 6 . The placebo group received injections of $2 \mathrm{~mL}$ of normal saline into the intraspinous ligament. Sixty patients achieved a $75 \%$ improvement on the ODI before week 6 and therefore did not receive 3 injections. The patients were assessed at 3, 6, 12, 26, and 52 weeks, with the primary outcome measure being the ODI and the criterion of response being a reduction of $75 \%$ from baseline, with secondary outcome measures of visual analog scale (VAS) and the ShortForm-36 (SF-36) questionnaire, etc. Based on the available literature, a reduction of $75 \%$ from baseline on the ODI is an unusual and unrealistic outcome measure as the literature considers a clinically important difference as an improvement of 4 points to 15 points (102-104,173-175). Even then, they reported a statistically significant improvement in self-reported function compared with placebo at 3 weeks. At the same time they reported that lumbar epidural corticosteroid injections did not produce a significant improvement in VAS leg pain, but did increase the number of patients reporting any improvement in leg pain using the Likert scale $(61 \%$ versus $40 \%, P<0.01)$. However, they reported that by 6 weeks the benefit of epidural steroids was lost, and at all subsequent visits there were no differences between the groups on any measures of outcome. At 52 weeks, 32.5\% of the active group and $29.6 \%$ of the placebo group had achieved a $75 \%$ improvement in ODI. Consequently, this result in both placebo and treatment group probably related to the natural course of the disease. Further, they also reported that after 12 months, 26 patients were pain free, with no difference between treatment groups, again illustrating the disadvantages of including patients with acute problems. Another outcome was that neurological symptoms and signs tended to improve throughout the trial, even though, at the end of the study, $44.8 \%$ of the patients still had decreased sensation and $24.6 \%$ decreased power. The authors describe that for the first time, a single large randomized controlled trial confirmed that epidural injections of corticosteroids offered short-term relief of symptoms in patients with sciatica at 3 weeks; however, they do not offer any medium- or long-term benefit in terms of symptoms, function, return to work, or the need for surgery. Further, the authors ignored many of the fundamental principles of contemporary interventional pain management, namely that no injections should be repeated unless the pain returns, the effect of steroids generally last approximately 4-6 weeks, and, by failing to use fluoroscopy, potentially providing nontargeted injections in approximately $50 \%$ to $80 \%$ of the patients.

Snoek et al (109) studied 51 patients with lumbar root compression documented by neurological deficit and a concordant abnormality noted on myelography. They compared the effects of $80 \mathrm{mg}$ of methylprednisolone $(2 \mathrm{~mL})$ and $2 \mathrm{~mL}$ of normal saline injected into the epidural space by the lumbar route. They found no significant differences between the 2 groups with respective relief of pain and a variety of physical parameters.

Wilson-MacDonald et al (125) compared lumbar epidural steroid injections to interspinous ligament steroid injections, to assess whether the epidural location of the steroid was responsible for the subsequent effects. Ninety-three patients with back and leg pain and MRI evidence of a prolapsed disc who had been offered surgery were randomized to receive either a blind lumbar epidural (44 patients) or an injection into the interspinous ligament (48 patients). Each patient was injected with 8 $\mathrm{mL} 0.5 \%$ bupivacaine and $80 \mathrm{mg}$ of methylprednisolone. There was no difference in the rate of subsequent surgery through the period of follow up.

\section{Effectiveness}

As shown in Table 10, of the 5 randomized trials (blind lumbar interlaminar epidurals) included in the evidence synthesis, 2 were positive for short-term and 5 of them providing long-term results were negative for long-term relief of more than 6 months. 
Table 10. Results of randomized trials of effectiveness of blind lumbar interlaminar epidural steroid injections in managing disc herniation and radiculitis.

\begin{tabular}{|c|c|c|c|c|c|c|c|c|c|}
\hline \multirow[b]{2}{*}{ Study } & \multirow[b]{2}{*}{$\begin{array}{c}\text { Study } \\
\text { Characteristics }\end{array}$} & \multirow[b]{2}{*}{$\begin{array}{l}\text { Methodological } \\
\text { Quality Scoring }\end{array}$} & \multirow[b]{2}{*}{ Participants } & \multicolumn{4}{|c|}{ Pain Relief } & \multicolumn{2}{|c|}{$\begin{array}{c}\text { Results } \\
\end{array}$} \\
\hline & & & & $\begin{array}{l}<3 \\
\text { mos. }\end{array}$ & 3 mos. & 6 mos. & 12 mos. & $\begin{array}{c}\text { Short-term } \\
\text { relief } \\
\leq 6 \mathrm{mos} .\end{array}$ & 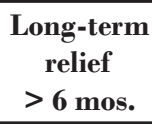 \\
\hline $\begin{array}{l}\text { Wilson- } \\
\text { MacDonald } \\
\text { et al } 2005 \\
(125)\end{array}$ & RA & 68 & 43 & SIT & NSD & NSD & NSD & $\mathrm{P}$ & $\mathrm{N}$ \\
\hline $\begin{array}{l}\text { Arden et al } \\
2005(126)\end{array}$ & RA,DB,PC & 86 & 228 & $75 \%$ & NSD & NSD & NSD & $\mathrm{N}$ & $\mathrm{N}$ \\
\hline $\begin{array}{l}\text { Carette et al } \\
1997 \text { (108) }\end{array}$ & RA,DB,PC & 77 & $\begin{array}{l}\mathrm{C}=80 \\
\mathrm{~T}=78\end{array}$ & SIT & NSD & NSD & NSD & $\mathrm{P}$ & $\mathrm{N}$ \\
\hline $\begin{array}{l}\text { Cuckler et al } \\
1985(110)\end{array}$ & $\mathrm{RA}, \mathrm{DB}$ & 60 & $\begin{array}{l}\mathrm{C}=31 \\
\mathrm{~T}=42\end{array}$ & NSD & NSD & NSD & NSD & $\mathrm{N}$ & $\mathrm{N}$ \\
\hline $\begin{array}{l}\text { Snoek et al } \\
1977(109)\end{array}$ & RA & 72 & $\begin{array}{l}\mathrm{C}=24 \\
\mathrm{~T}=27\end{array}$ & NSD & NSD & NSD & NSD & $\mathrm{N}$ & $\mathrm{N}$ \\
\hline
\end{tabular}

$\mathrm{RA}=$ randomized; $\mathrm{DB}=$ double blind $\mathrm{PC}=$ placebo controlled; $\mathrm{C}=$ control; $\mathrm{T}=$ treatment; $\mathrm{SIT}=$ significant improvement in treatment group; $\mathrm{NSD}=$ no significant difference; $\mathrm{P}$ = positive; $\mathrm{N}$ = negative; $\mathrm{NA}$ = not available

\section{Spinal Stenosis}

Two blind lumbar interlaminar randomized trials $(110,125)$ and one blind lumbar interlaminar observational study (150) evaluating spinal stenosis were identified.

\section{Study Characteristics}

Cuckler et al (110) included 37 patients from a sample of 73 patients with spinal stenosis of longer than 6 months. They injected in a randomized, double blind fashion either $7 \mathrm{~mL}$ of methylprednisolone acetate and procaine or $7 \mathrm{~mL}$ of physiological saline solution and procaine. No statistically significant difference was observed between the control and experimental patients. Long-term follow-up, averaging 20 months, failed to demonstrate the efficacy of a second injection of epidural steroids administered to the patients whose pain did not respond within 24 hours to an injection of either $80 \mathrm{mg}$ of methylprednisolone acetate combined with $5 \mathrm{~mL}$ of $1 \%$ procaine or $2 \mathrm{~mL}$ of sterile saline combined with $5 \mathrm{~mL}$ of $1 \%$ procaine. The multiple disadvantages of this study and various flaws are described in the disc herniation section.

Wilson-MacDonald et al (125) evaluated 18 patients in the epidural group and 14 patients in the control group with spinal stenosis only. Further, there were also 18 (control $=15$, epidural $=3$ ) patients with disc herniation and stenosis. Patients were treated either with an epidural steroid injection or an intramuscular injection of local anesthetic and steroids. Even though the results were negative, there was no significant difference in any of the groups on a longterm basis. However, there was a significant reduction in pain early on in those having an epidural steroid injection.

Campbell et al (150) in 2007 published results of the correlation of spinal canal dimensions to efficacy of epidural steroid injections in spinal stenosis. They included 84 patients in the study, 50 required surgical decompression after epidural steroid injection and 34 patients improved after epidural steroid injection. All the patients received lumbar interlaminar epidural injections. They concluded that spinal canal dimension is not predictive of success or failure of epidural steroid injection in patients with spinal stenosis. The study has been criticized that, on the basis of the study protocol, these conclusions may lead to confusion, rather than clarification (171). Further, patients received epidural steroid injections once a week in a series of 3 for 3 weeks, and the injections were performed without fluoroscopic guidance, using an interlaminar ap- 
proach, and were performed by 3 anesthesiologists from a single pain management clinic. Campbell et al (150) did not describe the volume of injectate nor the site of the injection. Further, routinely 3 epidurals were performed without any consideration as to whether the prior injection provided any relief or not, or if the patient continued to have pain or not. There were also other deficiencies with the presentation of the data. Overall it appears that $40 \%$ of the patients did not require decompression. Thus, it could be considered as to be a success. Basically,
Campbell et al (150) have demonstrated that epidural steroid injections performed blindly with an interlaminar approach in a series of 3 injections may still be effective. Consequently, the study illustrates that epidural steroids may be significantly effective in spinal stenosis if they are performed with the appropriate delivery of medication to the target site with a specific approach under fluoroscopy.

Table 11 shows the characteristics of the studies of lumbar interlaminar epidurals in managing spinal stenosis included in the evidence synthesis.

Table 11. Characteristics of published studies of blind lumbar interlaminar epidural injections in managing spinal stenosis.

\begin{tabular}{|c|c|c|c|c|c|}
\hline Study/Methods & Participants & Intervention(s) & Outcome(s) & Result(s) & $\begin{array}{l}\text { Conclusion(s) } \\
\text { Short-term } \\
\text { relief } \leq 6 \mathrm{mos} . \\
\text { Long-term } \\
\text { relief }>6 \mathrm{mos} .\end{array}$ \\
\hline $\begin{array}{l}\text { Cuckler et al } 1985 \\
(110) \\
\text { Randomized, } \\
\text { double-blind } \\
\text { trial }\end{array}$ & $\begin{array}{l}73 \text { pts. with back pain due to } \\
\text { either acute herniated nucleus } \\
\text { pulposus or spinal stenosis } \\
\text { of }>6 \text { mos. Experimental: } 42 \\
\text { Control: } 3.1\end{array}$ & $\begin{array}{l}\text { Experimental: } 80 \mathrm{mg} \\
(2 \mathrm{~mL}) \text { of methylpred- } \\
\text { nisolone }+5 \mathrm{~mL} \text { of } \\
\text { procaine } 1 \% . \\
\text { Control group: } 2 \\
\mathrm{~mL} \text { saline }+5 \mathrm{~mL} \text { of } \\
\text { procaine } 1 \% .\end{array}$ & $\begin{array}{l}\text { Timing: } 24 \text { hrs } \\
\text { and an average of } \\
20 \text { mos. } \\
\text { Outcome mea- } \\
\text { sures: subjective } \\
\text { improvement, } \\
\text { need for surgery. }\end{array}$ & $\begin{array}{l}\text { There was no signifi- } \\
\text { cant short-term or } \\
\text { long-term improve- } \\
\text { ments between both } \\
\text { groups. }\end{array}$ & $\begin{array}{l}\text { Negative short- } \\
\text { term and long- } \\
\text { term relief }\end{array}$ \\
\hline $\begin{array}{l}\text { Wilson-MacDonald } \\
\text { et al } 2005 \text { (125) } \\
\text { Randomized, } \\
\text { controlled trial }\end{array}$ & $\begin{array}{l}93 \text { pts. with MRI evidence of a } \\
\text { disc prolapse, spinal stenosis, } \\
\text { or a combination. } \\
\text { Pts. had lumbosacral nerve } \\
\text { root pain which had not re- } \\
\text { solved within } 6 \text { wks minimum. } \\
32 \text { pts. with } 18 \text { in the epidu- } \\
\text { ral group and } 14 \text { in the control } \\
\text { group had spinal stenosis only, } \\
\text { whereas } 3 \text { pts. in the epidu- } \\
\text { ral group and } 15 \text { pts. in control } \\
\text { group had a combined disc } \\
\text { herniation and spinal stenosis. }\end{array}$ & $\begin{array}{l}\text { Experimental: } \\
\text { epidural injection of } \\
\text { bupivacaine } 0.5 \% \text { ( } 40 \\
\text { mg) with methyl- } \\
\text { prednisolone } 80 \mathrm{mg} \text {. } \\
\text { Control: intramuscu- } \\
\text { lar injection of } 0.5 \% \\
\text { ( } 40 \mathrm{mg} \text { ) bupiva- } \\
\text { caine with } 80 \mathrm{mg} \\
\text { methylprednisolone. }\end{array}$ & $\begin{array}{l}\text { Timing: } 6 \text { wks, } 24 \\
\text { mos. Outcome } \\
\text { measures: Os- } \\
\text { westry Disability } \\
\text { index, pain relief. }\end{array}$ & $\begin{array}{l}\text { In the first } 5 \text { wks af- } \\
\text { ter epidural injection } \\
\text { a useful improve- } \\
\text { ment in nerve root } \\
\text { symptoms was seen. }\end{array}$ & $\begin{array}{l}\text { Negative short- } \\
\text { and long-term } \\
\text { relief }\end{array}$ \\
\hline $\begin{array}{l}\text { Campbell et al } \\
2007 \text { (150) } \\
\text { Observational } \\
\text { study }\end{array}$ & $\begin{array}{l}84 \text { patients with lumbar spinal } \\
\text { stenosis. }\end{array}$ & $\begin{array}{l}\text { Pts. received an } \\
\text { epidural steroid injec- } \\
\text { tion once a week for } \\
3 \text { weeks performed } \\
\text { without fluoroscopic } \\
\text { assistance, using an } \\
\text { interlaminar approach } \\
\text { performed by } 3 \text { anes- } \\
\text { thesiologists from a } \\
\text { single pain manage- } \\
\text { ment clinic. }\end{array}$ & $\begin{array}{l}\text { 24-month fol- } \\
\text { low-up being } \\
\text { differentiated into } \\
\text { patients requiring } \\
\text { surgery and those } \\
\text { not requiring } \\
\text { surgery. }\end{array}$ & $\begin{array}{l}\text { Spinal canal dimen- } \\
\text { sion is not predictive } \\
\text { of success or failure } \\
\text { of lumbar interlami- } \\
\text { nar epidural steroid } \\
\text { injections in pts. with } \\
\text { spinal stenosis. The } \\
\text { results showed } 50 \text { pts. } \\
\text { requiring surgical } \\
\text { decompression and } \\
34 \text { pts. improved } \\
\text { after epidural steroid } \\
\text { injection; } 3 \text { injections } \\
\text { performed blindly in } \\
\text { a series were effective } \\
\text { in approximately } 40 \% \\
\text { of the pts. in avoiding } \\
\text { surgery. }\end{array}$ & $\begin{array}{l}\text { Short-term not } \\
\text { available and long- } \\
\text { term negative }\end{array}$ \\
\hline
\end{tabular}




\section{Effectiveness}

Of the 3 evaluations studying the effectiveness of blind lumbar interlaminar epidural injections in spinal stenosis, none were shown to be positive for shortterm or long-term relief.

Table 12 shows the results of 3 studies evaluating the effectiveness of blind lumbar interlaminar epidural injections in managing chronic low back or lower extremity pain of spinal stenosis.

\section{Chronic Low Back Pain of Discogenic Origin without Radiculitis or Disc Herniation}

There were no randomized trials in the evaluation of low back pain without disc herniation or radiculitis.

However, there was one observational study available evaluating the effect of spinal steroid injections for degenerative disc disease under fluoroscopy, which included intradiscal injections as well as interlaminar epidural injections (148). Epidural steroid injections were performed in 93 patients with degenerative disc disease and inflammatory endplate changes and in 139 patients without inflammatory endplate changes. The patients with inflammatory endplate changes $(n=78)$ or without inflammatory endplate changes $(n=93)$, all of whom were considered fusion candidates, underwent discography with or without intradiscal steroid in a randomized fashion. Pain and function were prospectively determined by a self-administered outcome survey (VAS pain, ODI, pain diagram [PD], and opinion of success) before and after the patients' injections for a 2-year follow-up. MRI and discography results were correlated with patient outcome scores. Patients received either interlaminar or transforaminal epidural steroid injections, all of which were performed under fluoroscopy; however, the proportion of patients receiving interlaminar epidural steroid injections is not described. However, this study over a period of 2 years had an extensive dropout rate of $60 \%$. Ultimately, at 2 years, 49 of the 139 patients (35\%) in this group had undergone a fusion. Of the patients who had implemented endplate changes ( $n=93$ ), approximately one-half of the patients expressed a positive opinion as to whether the epidural steroid injection was successful in the treatment of their symptoms during the first 3 months. Over subsequent follow-up periods, the success rate declined. The use of pain medication was found generally to have decreased during followup periods. The outcome scores for pain and disability showed significant improvement for back and leg pain (VAS and pain drawing) $(P<0.001)$.

Of the 139 patients who did not have inflammatory endplate changes and were treated with epidural steroid injections, 98 had not changed treatment after 3 month follow-up. Patients' self assessment of success slowly declined over time so that after one year, only 32 of the original 139 patients in this group considered their injection therapy to have been successful. However, a significant improvement in all outcome scales was found at all follow-up periods for those patients who did not drop out $(P<0.001)$.

A comparison of the 2 epidural steroid groups (inflammatory versus non-inflammatory endplates) revealed greater improvement for ODI scores for the

Table 12. Results of published studies of effectiveness of blind lumbar interlaminar epidural steroid injections in managing spinal stenosis.

\begin{tabular}{|c|c|c|c|c|c|c|c|c|c|}
\hline \multirow[b]{2}{*}{ Study } & \multirow[b]{2}{*}{$\begin{array}{c}\text { Study } \\
\text { Characteristics }\end{array}$} & \multirow[b]{2}{*}{$\begin{array}{l}\text { Methodological } \\
\text { Quality Scoring }\end{array}$} & \multirow[b]{2}{*}{ Participants } & \multicolumn{4}{|c|}{ Pain Relief } & \multicolumn{2}{|c|}{ Results } \\
\hline & & & & $\begin{array}{l}<3 \\
\text { mos. }\end{array}$ & $\begin{array}{c}3 \\
\text { mos. }\end{array}$ & $\begin{array}{c}6 \\
\operatorname{mos} .\end{array}$ & $\begin{array}{c}12 \\
\text { mos. }\end{array}$ & $\begin{array}{c}\text { Short- } \\
\text { term } \\
\text { relief } \\
\leq 6 \text { mos. }\end{array}$ & $\begin{array}{c}\text { Long- } \\
\text { term } \\
\text { relief }> \\
6 \text { mos. }\end{array}$ \\
\hline $\begin{array}{l}\text { Cuckler et al } \\
1985(110)\end{array}$ & RA,DB & 60 & 37 & NSD & NSD & NSD & NSD & $\mathrm{N}$ & $\mathrm{N}$ \\
\hline $\begin{array}{l}\text { Wilson- } \\
\text { MacDonald et al } \\
2005 \text { (125) }\end{array}$ & RA & 68 & 32 & SI & NSD & NSD & NSD & $\mathrm{P}$ & $\mathrm{N}$ \\
\hline $\begin{array}{l}\text { Campbell et al } \\
2007 \text { (150) }\end{array}$ & $\mathrm{O}$ & 53 & 84 & NA & NA & NA & $40 \%$ & NA & $\mathrm{N}$ \\
\hline
\end{tabular}

$\mathrm{RA}=$ randomized $\mathrm{DB}=$ double blind $\mathrm{O}=$ observational $\mathrm{C}=$ control; $\mathrm{T}=$ treatment $\mathrm{SI}=$ significant improvement $\mathrm{NSD}=$ no significant difference; $\mathrm{P}$ = positive; $\mathrm{N}$ = negative; $\mathrm{NA}=$ not available 
patients with inflammatory endplates at one to 3 and 4 to 6 month follow-up periods and pain drawing at the 4 to 6 month follow-up period. In addition, epidural steroid injection patients in the subgroup without inflammatory endplates were found to be using less pain medication in the early post treatment period. In addition, dropout rates were greater, although not significantly, for those without inflammatory endplates at all follow-up periods. The authors concluded that patients may have short-term benefit by epidural steroid injection without disc herniation or stenosis. Overall, $25 \%$ to $35 \%$ of patients with chronic low back pain resulting from degenerative disc disease had improved pain and function after epidural steroid injection at 2-year follow-up.

\section{Effectiveness}

Only one observational study (148) showed moderate results with short-term positive results and with negative long-term results in patients with chronic low back pain of discogenic origin without radiculitis or disc herniation.

\section{Cost Effectiveness}

In evaluations of cost effectiveness, Manchikanti et al (176) and Price et al (177) concluded that interlaminar epidural steroid injections were not cost effective.

\section{Level of Evidence}

The evidence-based on USPSTF criteria (105) is Level II-2 for blind lumbar interlaminar epidural injections for short-term relief in managing chronic low back and lower extremity pain secondary to lumbar disc herniation and/or radiculitis. The evidence is Level III for blind lumbar interlaminar epidural injections in managing low back pain of spinal stenosis, and chronic low back pain of discogenic origin without disc herniation or radiculitis.

\section{Recommendations}

Based on Guyatt et al's criteria (106), the recommendation for disc herniation and radiculitis for blind lumbar interlaminar epidural injections is $1 \mathrm{C}$, a strong recommendation which may change when higher quality evidence becomes available for short-term relief. However, for long-term relief, the recommendation is $2 B$, with weak recommendation, with best action differing depending on circumstances or patients' or societal values. For spinal stenosis and discogenic pain without disc herniation and radiculitis, the evidence is Level III with $2 \mathrm{C} /$ weak recommendation, other alternatives may be equally reasonable.

\section{Complications}

The common complications of interlaminar epidural injections are of 2 types: those related to the needle placement, and those related to drug administration $(1,58,59,147,163-171,178)$. Infectious complications include epidural abscess, meningitis, and osteomyelitis/ discitis. Epidural hematomas are potentially the most serious of the epidural injection complications. Epidural hematomas can develop spontaneously even in patients with no evidence of any bleeding tendency, anticoagulation, or traumatic needle insertion. Neurological injuries are an uncommon complication that can occur when performing lumbar epidural steroid injections. Other complications include increased pain, seizures, chemical meningitis, dural puncture, subdural air, pneumocephalus, transient blindness, retinal necrosis, chorioretinopathy, hiccups, flushing, and arterial gas embolism (178-194). Side effects related to the administration of steroids are generally attributed either to the chemistry or the pharmacology of the steroids (195-199). The major theoretical complications of corticosteroid administration include suppression of pituitary adrenal axis, hypercorticism, Cushing's syndrome, osteoporosis, avascular necrosis of the bone, steroid myopathy, epidural lipomatosis, weight gain (200), fluid retention, and hyperglycemia.

The most commonly used steroids in neural blockade in the United States, methylprednisolone acetate, triamcinolone acetamide, and betamethasone acetate and phosphide mixture, have all been shown to be safe at epidural therapeutic doses in both clinical and experimental studies. It has been shown that at therapeutic doses of epidural steroids administered, complications were not noted (199).

Finally, radiation exposure is also a potential problem with damage to eyes, skin, and gonads (201-204).

\section{Discussion}

This systematic review of blind lumbar interlaminar epidural injections in managing chronic low back pain and lower extremity pain of disc herniation or radiculitis showed an indicated evidence of Level II2 for short-term relief with evidence lacking with Level III for long-term relief. The evidence is lacking with Level III for spinal stenosis and discogenic pain. We have not evaluated the evidence for lumbar post- 
laminectomy syndrome as this is not a commonly performed procedure and is considered unsafe with an interlaminar approach. The recommendation provided for short-term relief in disc herniation, based on Guyatt et al's (106) criteria is $1 \mathrm{C} /$ strong recommendation which may change when higher quality evidence becomes available for short-term management for patients with lumbar disc herniation and radiculitis. The recommendation is $2 \mathrm{~B} / \mathrm{w}$ weak recommendation for long-term management of patients with disc herniation and radiculitis, with best action differing depending on circumstances or patients' or societal values. For low back and lower extremity pain secondary to spinal stenosis and disc degeneration without disc herniation or radiculitis, the recommendation is $2 \mathrm{C} /$ very weak recommendation, where other alternatives may be equally reasonable.

In addition to the paucity of available literature meeting inclusion criteria, all of the included studies followed flawed methodology without target delivery of steroids, delivering them without fluoroscopy, performing the procedures frequently between L3/4 and occasionally L4/5 in the lateral position, with poor assessment of outcomes application and analysis. The disadvantages of this approach without fluoroscopy include dilution of the injectate, extra epidural placement of the needle, intravascular placement of the needle, preferential cranial flow of the solution, preferential posterior flow of the solution, difficult placement (with increased risks in post-surgical patients), difficult placement below L4-L5 interspace, deviation of needle to non-dependent side, dural puncture, and trauma to spinal cord. There was a paucity of literature in the evaluation of spinal stenosis, whereas there was only one observational study available in evaluating chronic discogenic pain without disc herniation or radiculitis.

The ultimate results of this systematic review are similar to previous systematic reviews and guidelines. However, in this evaluation we attempted to evaluate the evidence separately for disc herniation and radiculitis, spinal stenosis, and chronic discogenic pain, whereas others have evaluated by combining multiple conditions and multiple techniques (caudal and transforaminal) into one category. In addition, in this study we have expanded the definition of short-term relief to 6 months or less, whereas long-term relief is defined as longer than 6 months - a robust measure. Even then, the results were only positive for shortterm relief for disc herniation and radiculitis, whereas they were negative or inconclusive for all other conditions and for long-term relief for disc herniation and radiculitis.

The evidence here is inferior compared to caudal epidural with or without steroids $(95,96)$. Further, when the injections were performed under fluoroscopy, caudal epidurals showed superior results (88-91) in all conditions, including discogenic pain without disc herniation, spinal stenosis, and post surgery syndrome. Even blind injections showed superior results with cervical epidurals in the management of chronic neck pain. One of the reasons may be that the target delivery of steroids is much easier in the cervical epidural space than in the lumbar epidural space $(74,95,205,206)$. Thus, the results of this evaluation with all flawed evidence, even though it looks appropriate based on the methodologic quality assessment, may not be utilized in contemporary clinical practice of interventional pain management.

Target site concentration of the administered drug including steroids depends on multiple injection variables including the route of administration. Interlaminar epidural injections are considered to be non-specific. Steroids may be prevented from migrating from the posterior epidural space to the anterior or ventral epidural space by the presence of epidural ligaments or scar tissue, with interlaminar administration. The extra epidural placement of the needle, which may go unrecognized without fluoroscopic guidance, is of paramount importance with the interlaminar approach $(147,163-171)$. Other disadvantages of the interlaminar approach include erroneous placement of the needle, which may miss the targeted interspace without fluoroscopic guidance; preferential cranial flow of the solution in the epidural space; deviation of the needle to the non-dependent side; difficulty entering the epidural space and delivery of injectate below L5, for S1 nerve root involvement; potential risk of dural puncture and post-lumbar puncture headache; and finally, the rare, but serious risk of spinal cord trauma $(147,163-171)$. It is a well-known fact that disc herniation mostly involves L4-L5 and L5S1 discs and the preferential flow to higher levels by placing the needle at L3-4 obviates the entire philosophy of target delivery. Advocates of fluoroscopic guidance point to several studies which have shown that in as many as $30 \%$ of the lumbar epidural injections by experienced injectionists, the epidural space was misidentified (147,163-169). In fact, Botwin et al (169) in their prospective evaluation of epidurography con- 
trast patterns in fluoroscopically guided lumbar interlaminar epidural injections found that dorsal contrast spread occurred in all patients, whereas ventral spread was present in only $36 \%$ of the patients. In addition, they also showed that the mean number of vertebral levels of cephalad spread was 1.28 and caudal spread was 0.88 . In another study (170), the spread was unilateral $45 \%$ of the time and the contrast spread was anterior only $43 \%$ to $51 \%$ of the time based on the needle position, indicating over $49 \%$ of the time it was posterior.

The results of this systematic review are similar to previous systematic reviews and guideline syntheses $(1,45-52)$. However, while some previous reviews $(1,58,70)$ evaluated the evidence based on the route of administration - namely caudal, transforaminal, or lumbar interlaminar, others $(62,65,66)$ have evaluated by combining multiple conditions and multiple techniques into one category, invariably leading to wrong conclusions $(71,72,207)$. Further, in this study we have expanded the definition of short-term relief to 6 months or less, whereas long-term relief is defined as longer than 6 months, providing robust evidence. In addition, this is the first systematic review of the effectiveness of lumbar interlaminar epidural steroid injections as a separate category for lumbar interlaminar, spinal stenosis, and discogenic chronic low back pain.

The debate concerning caudal epidural steroid injections has been nurtured since the 1970s $(1,58,59,62,65,66,70)$. The first systematic review of the effectiveness of caudal epidural steroid injections was performed by Kepes and Duncalf in 1985 (61). They concluded that the rationale for epidural and systematic steroids was not proven. However, in 1986, Benzon (73), utilizing the same studies, concluded that mechanical causes of low back pain, especially those accompanied by signs of nerve root irritation, may respond to epidural steroid injections. Thus, this illustrates that systematic reviews can be, and have been, providing different results based on the evaluators. More recently, ACOEM guidelines $(68,69)$ provided negative evidence for lumbar interlaminar epidural injections. The debate concerning epidural steroid injections took center stage in the 1980s and 1990s with multiple publications $(59,63)$. Bogduk et al $(59)$ extensively studied interlaminar, caudal, and transforaminal epidural injections, including all the literature available at the time, and concluded that the balance of published evidence supports the therapeutic use of caudal epidurals. In 1995, Koes et al (62) reviewed 12 trials of lumbar and caudal epidural steroid injections and reported positive results from only 6 studies. However, a review of their analysis showed that there were 5 studies for caudal epidural steroid injections and 7 studies for lumbar epidural steroid injections and 5 of the 7 studies for lumbar interlaminar were negative. Their updated analysis (63) with the inclusion of 15 trials also arrived at the same conclusions. Multiple other investigators $(62,65,66)$ also have provided differing conclusions, all negative. In general, criticism against systematic reviews in the past has been directed toward methodology, small size of the study populations, and other limitations, including long-term follow-up and outcome parameters on the available literature. Further, paucity of literature has been a factor in the systematic evaluation of evidence for the effectiveness of epidural injections.

\section{Conclusion}

This systematic review of blind lumbar interlaminar epidural injections in managing chronic low back pain and lower extremity pain of disc herniation or radiculitis showed an indicated evidence of Level II-2 for short-term relief with lacking of evidence with Level III for long-term relief and lacking of evidence with Level III for short- and long-term relief for spinal stenosis and discogenic pain. Caution must be exercised in the interpretation of these findings as all the studies included in this evaluation are blind interlaminar epidural injections and do not represent contemporary interventional pain management practice.

\section{ACKNOWLedgements}

The authors wish to thank the editorial board of Pain Physician, for review and criticism in improving the manuscript; Vidyasagar Pampati, MSc, statistician; Sekar Edem for assistance in search of literature; and Tonie M. Hatton and Diane E. Neihoff, transcriptionists (Pain Management Center of Paducah), for their assistance in the preparation of this manuscript. 


\section{References}

1. Boswell MV, Trescot AM, Datta S, Schultz DM, Hansen HC, Abdi S, Sehgal N, Shah RV, Singh V, Benyamin RM, Patel VB, Buenaventura RM, Colson JD, Cordner HJ, Epter RS, Jasper JF, Dunbar EE, Atluri SL, Bowman RC, Deer TR, Swicegood JR, Staats PS, Smith HS, Burton AW, Kloth DS, Giordano J, Manchikanti L. Interventional techniques: Evidencebased practice guidelines in the management of chronic spinal pain. Pain Physician 2007; 10:7-111.

2. Gureje O, Von Korff M, Simon GE, Gater R. Persistent pain and well-being: $A$ World Health Organization Study in Primary Care. JAMA 1998; 280:147-151.

3. Verhaak PF, Kerssens JJ, Dekker J, Sorbi MJ, Bensing JM. Prevalence of chronic benign pain disorder among adults: A review of the literature. Pain 1998; 77:231-239.

4. Elliott AM, Smith BH, Hannaford PC, Smith WC, Chambers WA. The course of chronic pain in the community: Results of a 4-year follow-up study. Pain 2002; 99:299-307.

5. Bressler HB, Keyes WJ, Rochon PA, Badley $E$. The prevalence of low back pain in the elderly. A systemic review of the literature. Spine 1999; 24:1813-1819.

6. Lawrence RC, Helmick CG, Arnett FC. Estimates of the prevalence of arthritis and selected musculoskeletal disorders in the United States. Arthritis Rheum 1998; 41:778-799.

7. Cassidy JD, Carroll LJ, Cotê P. The Saskatchewan Health and Back Pain Survey. The prevalence of low back pain and related disability in Saskatchewan Adults. Spine 1998; 23:1860-1867.

8. Luo X, Pietrobon R, Sun SX, Liu GG, Hey L. Estimates and patterns of direct health care expenditures among individuals with back pain in the United States. Spine 2004; 29:79-86.

9. Bell G, Kidd D, North R. Cost-effectiveness analysis of spinal cord stimulation in treatment of failed back surgery syndrome. J Pain Symp Manage 1997; 13:286-295.

10. Ricci JA, Stewart WF, Chee E, Leotta C, Foley K, Hochberg MC. Back pain exacerbations and lost productive time costs in United States workers. Spine 2006; 31:3052-3060.

11. Stewart WF, Ricci JA, Chee E, Morganstein $\mathrm{D}$, Lipton $\mathrm{R}$. Lost productive time and cost due to common pain con- ditions in the US workforce. JAMA 2003; 290:2443-2454.

12. Leigh JP, Markowitz SB, Fahs M, Shin C, Landrigan PJ. Occupational injury and illness in the United States. Estimates of costs, morbidity, and mortality. Arch Intern Med 1997; 157:1557-1568.

13. Kuslich SD, Ulstrom CL, Michael C). The tissue origin of low back pain and sciatica: A report of pain response to tissue stimulation during operation on the lumbar spine using local anesthesia. Orthop Clin North Am 1991; 22:181-187.

14. Mixter WJ, Barr JS. Rupture of the intervertebral disc with involvement of the spinal canal. N Eng J Med 1934; 211:210215.

15. Mixter WJ, Ayers JB. Herniation or rup ture of the intervertebral disc into the spinal canal. N Engl J Med 1935; 213:385-395.

16. Pang WW, Mok MS, Lin ML, Chang DP, Hwang MH. Application of spinal pain mapping in the diagnosis of low back pain-analysis of 104 cases. Acta Anaesthesiol Sin 1998; 36:71-74.

17. Manchikanti L, Singh V, Pampati V, Damron K, Barnhill R, Beyer C, Cash K. Evaluation of the relative contributions of various structures in chronic low back pain. Pain Physician 2001; 4:308-316.

18. Hirsch C. An attempt to diagnose level of disc lesion clinically by disc puncture. Acta Orthop Scand 1948; 18:132-140.

19. Schwarzer AC, Aprill CN, Derby R, Fortin J, Kine G, Bogduk N. The prevalence and clinical features of internal disc disruption in patients with chronic low back pain. Spine 1995; 20:1878-1883

20. Crock HV. A reappraisal of intervertebral disc lesions. Med J Aust 1970; 1:983 989.

21. Ohnmeiss DD, Vanharanta H, Ekholm J. Degree of disc disruption and lower extremity pain. Spine 1997; 22:16001605.

22. Wheeler AH, Murrey DB. Chronic lumbar spine and radicular pain: Pathophysiology and treatment. Curr Pain Headache Rep 2002; 6:97-105.

23. Wolfer L, Derby R, Lee JE, Lee SH. Systematic review of lumbar provocation discography in asymptomatic subjects with a meta-analysis of false-positive rates. Pain Physician 2008; 11:513-538.

24. Hadjipavlou AG, Tzermiadianos MN, Bogduk N, Zindrick MR. The pathophys- iology of disc degeneration: A critical review. J Bone Joint Surg Br 2008; 90:1261-1270.

25. McCarron RF, Wimpee MW, Hudkins PG, Laros GS. The inflammatory effects of nucleus pulposus: A possible element in the pathogenesis of low back pain. Spine 1987; 12:760-764.

26. Olmarker K, Nordborg C, Larsson K, Rydevik B. Ultrastructural changes in spinal nerve roots induced by autologous nucleus pulposus. Spine 1996; 27:411-414.

27. Olmarker K, Rydevik B, Nordborg C. Autologous nucleus pulposus induces neurophysiologic and histologic changes in porcine cauda equina nerve roots. Spine 1993; 18:1425-1432.

28. Norimoto M, Ohtori S, Yamashita M, Inoue G, Yamauchi K, Koshi T, Suzuki M, Orita S, Eguchi Y, Sugiura A, Ochiai N, Takaso M, Takahashi K. Direct application of the TNF-alpha inhibitor, etanercept, does not affect CGRP expression and phenotypic change of DRG neurons following application of nucleus pulposus onto injured sciatic nerves in rats. Spine 2008; 33:2403-2408.

29. Genevay S, Finckh A, Payer M, Mezin F, Tessitore E, Gabay C, Guerne PA. Elevated levels of tumor necrosis factoralpha in periradicular fat tissue in patients with radiculopathy from herniated disc. Spine 2008; 33:2041-2046.

30. Sugiura A, Ohtori S, Yamashita M, Inoue G, Yamauchi K, Koshi T, Suzuki M, Norimoto M, Orita S, Eguchi Y, Takahashi Y, Watanabe TS, Ochiai N, Takaso M, Takahashi K. Existence of nerve growth factor receptors, tyrosine kinase $a$ and p75 neurotrophin receptors in intervertebral discs and on dorsal root ganglion neurons innervating intervertebral discs in rats. Spine 2008; 33:2047-2051.

31. Yamashita M, Ohtori S, Koshi T, Inoue G, Yamauchi K, Suzuki M, Takahashi $\mathrm{K}$. Tumor necrosis factor-alpha in the nucleus pulposus mediates radicular pain, but not increase of inflammatory peptide, associated with nerve damage in mice. Spine 2008; 33:1836-1842.

32. Olmarker K, Rydevik B, Holm S. Edema formation in spinal nerve roots induced by experimental, graded compression: An experimental study on the pig cauda equina with special reference to differences in effects between rapid 
and slow onset of compression. Spine 1989; 14:569-573.

33. Olmarker K, Rydevik B, Holm S, Bagge U. Effects of experimental graded compression on blood flow in spinal nerve roots: A vital microscopic study on the porcine cauda equina. J Orthop Res 1989; 7:817-823.

34. Olmarker K, Holm S, Rydevik B. Importance of compression onset rate for the degree of impairment of impulse propagation in experimental compression injury of the porcine cauda equina. Spine 1990; 35:416-419.

35. Rydevik BL. The effects of compression on the physiology of nerve roots. J Manipul Physiol Ther 1992; 1:62-66.

36. Olmarker $\mathrm{K}$, Holm S, Rosenqvist AL, Rydevik B. Experimental nerve root compression. Presentation of a model for acute, graded compression of the porcine cauda equina, with analysis of neural and vascular anatomy. Spine 1992; 16:61-69.

37. Olmarker K, Rydevik B. Selective inhibition of tumor necrosis factor-alpha prevents nucleus pulposus-induced thrombus formation, intraneural ede$\mathrm{ma}$, and reduction of nerve conduction velocity: Possible implications for future pharmacologic treatment strategies of sciatica. Spine 2001; 26:863869.

38. Igarashi T, Kikuchi S, Shubayev V, Myers RR. 2000 Volvo Award winner in basic science studies: Exogenous tumor necrosis factor-alpha mimics nucleus pulposus-induced neuropathology. Molecular, histologic, and behavioral comparisons in rats. Spine 2000; 25:2975-2980.

39. Homma Y, Brull SJ, Zhang JM. A comparison of chronic pain behavior following local application of tumor necrosis factor alpha to the normal and mechanically compressed lumbar ganglia in the rat. Pain 2002; 95:239-246.

40. Miyamoto H, Saura R, Doita M, Kurosaka M, Mizuno K. The role of cyclooxygenase-2 in lumbar disc herniation. Spine 2002; 27:2477-2483.

41. Cummins J, Lurie JD, Tosteson TD, Hanscom B, Abdu WA, Birkmeyer NJ, Herkowitz $\mathrm{H}$, Weinstein J. Descriptive epidemiology and prior healthcare utilization of patients in the Spine Patient Outcomes Research Trial's (SPORT) three observational cohorts: Disc herniation, spinal stenosis, and degener- ative spondylolisthesis. Spine 2006; 31:806-814.

42. Cherkin DC, Deyo RA, Loeser JD, Bush T, Waddell G. An international comparison of back surgery rates. Spine 1994; 19:1201-1206.

43. Deyo RA, Ciol MA, Cherkin DC, Loeser JD, Bigos SJ. Lumbar spinal fusion: A cohort study of complications, reoperations, and resource use in the Medicare population. Spine 1993; 18:14631470.

44. Deyo RA, Gray DT, Kreuter W, Mirza S, Martin Bl. United States trends in lumbar fusion surgery for degenerative conditions. Spine 2005; 30:1441-1445.

45. Gibson JNA, Waddell G, Grant IC. Surgery for degenerative lumbar spondylolysis. Cochrane Database Syst Rev 2000; 3:CDo01352.

46. Schofferman J, Reynolds J, Herzog R, Covington E, Dreyfuss P, O'Neill C. Failed back surgery: Etiology and diag. nostic evaluation. Spine J 2003; 3:400403.

47. Slipman CW, Shin $\mathrm{CH}$, Patel RK, Isaac Z, Huston CW, Lipetz JS, Lenrow DA, Braverman DL, Vresilovic EJ Jr. Etiologies of failed back surgery syndrome. Pain Med 2002; 3:200-214.

48. Waguespack A, Schofferman J, Slosar $P$, Reynolds J. Etiology of long-term failures of lumbar spine surgery. Pain Med 2002; 3:18-22.

49. Waddell G, Kummel EG, Lotto WN, Graham JD, Hall H, McCulloch JA. Failed lumbar disc surgery and repeat surgery following industrial injury. J Bone Joint Surg Am 1979; 61:201-207.

50. Ross JS, Robertson JT, Frederickson RC, Petrie JL, Obuchowski N, Modic MT, de Tribolet N. Association between peridural scar and recurrent radicular pain after lumbar discectomy: Magnetic resonance evaluation. Neurosurgery 1996; 38:855-863.

51. Fritsch EW, Heisel J, Rupp S. The failed back surgery syndrome. Reasons, intraoperative findings, and long-term results: A report of 182 operative treatments. Spine 1996; 21:626-633.

52. Specialty Utilization data files from CMS: www.cms.hhs.gov/

53. Manchikanti L, Boswell MV. Interventional techniques in ambulatory surgical centers: A look at the new payment system. Pain Physician 2007; 10:627650.
54. Manchikanti L. The growth of interventional pain management in the new millennium: A critical analysis of utilization in the Medicare population. Pain Physician 2004; 7:465-482.

55. Manchikanti L, Giordano J. Physician payment 2008 for interventionalists: Current state of health care policy. Pain Physician 2007; 10:607-626.

56. Friedly J, Chan L, Deyo R. Increases in lumbosacral injections in the Medicare population: 1994 to 2001. Spine 2007; 32:1754-1760.

57. Friedly J, Nishio I, Bishop MJ, Maynard C. The relationship between repeated epidural steroid injections and subsequent opioid use and lumbar surgery. Arch Phys Med Rehabil 2008; 89:10111015.

58. Abdi S, Datta S, Trescot AM, Schultz DM, Adlaka R, Atluri SL, Smith HS, Manchikanti L. Epidural steroids in the management of chronic spinal pain: A systematic review. Pain Physician 2007; 10:185-212.

59. Bogduk N, Christophidis N, Cherry D. Epidural use of steroids in the management of back pain. Report of working party on epidural use of steroids in the management of back pain. National Health and Medical Research Council. Canberra, Commonwealth of Australia, 1994, pp 1-76.

6o. Bogduk N. Epidural steroids for low back pain and sciatica. Pain Digest 1999; 9:226-227.

61. Kepes ER, Duncalf D. Treatment of backache with spinal injections of local anesthetics, spinal and systemic steroids. Pain 1985; 22:33-47.

62. Koes BW, Scholten RJ, Mens JM, Bouter LM. Efficacy of epidural steroid injections for low back pain and sciatica: A systematic review of randomized clinical trials. Pain 1995; 63:279-288.

63. Koes BW, Scholten RJ, Mens JMA, Bouter LM. Epidural steroid injections for low back pain and sciatica: An updated systematic review of randomized clinical trials. Pain Digest 1999; 9:241-247.

64. Airaksinen O, Brox JI, Cedraschi C, Hildebrandt J, Klaber-Moffett J, Kovacs F, Mannion AF, Reis S, Staal JB, Ursin H, Zanoli G. Chapter 4: European guidelines for the management of chronic nonspecific low back pain. Eur Spine J 2006; 15:S192-S300.

65. Armon C, Argoff CE, Samuels J, Backonja MM; Therapeutics and Technol- 
ogy Assessment Subcommittee of the American Academy of Neurology. Assessment: Use of epidural steroid injections to treat radicular lumbosacral pain: Report of the Therapeutics and Technology Assessment Subcommittee of the American Academy of Neurology. Neurology 2007; 68:723-729.

66. Staal JB, de Bie R, de Vet HC, Hildebrandt J, Nelemans P. Injection therapy for subacute and chronic low-back pain. Cochrane Database Syst Rev 2008; 3:CDoo1824.

67. Denniston PL. Official Disability Guidelines, 13th ed. Work Loss Data Institute, 2008.

68. American College of Occupational and Environmental Medicine. Low Back Disorders Chapter. In: Occupational Medicine Practice Guidelines: Evaluation and Management of Common Health Problems and Functional Recovery of Workers, Second Edition. American College of Occupational and Environmental Medicine, Elk Grove Village, 2007.

69. American College of Occupational and Environmental Medicine. Chronic Pain Chapter (revised 2008). In: Occupational Medicine Practice Guidelines: Evaluation and Management of Common Health Problems and Functional Recovery of Workers, Second Edition. American College of Occupational and Environmental Medicine, Elk Grove Village, Epublished August 14, 2008.

70. Manchikanti L, Singh V, Derby R, Schultz DM, Benyamin RM, Prager JP, Hirsch JA. Reassessment of evidence synthesis of occupational medicine practice guidelines for interventional pain management. Pain Physician 2008; 11:393482.

71. Manchikanti L, Singh V, Derby R, Helm S, Trescot AM, Staats PS, Prager JP, Hirsch JA. Review of occupational medicine practice guidelines for interventional pain management and potential implications. Pain Physician 2008; 11:271-289.

72. Manchikanti L, Singh V, Helm S, Trescot AM, Hirsch JA. A critical appraisal of 2007 American College of Occupational and Environmental Medicine (ACOEM) practice guidelines for interventional pain management: An independent review utilizing AGREE, AMA, IOM, and other criteria. Pain Physician 2008; 11:291-310.

73. Benzon HT. Epidural steroid injections for low back pain and lumbosacral radiculopathy. Pain 1986; 24:277-295.

74. Pasqualucci $A$, Varrassi $G$, Braschi $A$, Peduto VA, Brunelli A, Marinangeli F, Gori F, Colò F, Paladín A, Mojoli F. Epidural local anesthetic plus corticosteroid for the treatment of cervical brachial radicular pain: Single injection verus continuous infusion. Clin J Pain 2007; 23:551-557.

75. Katz WA, Rothenberg R. The nature of pain: Pathophysiology. J Clin Rheumatol 2005; 11(2 suppl):S11-15.

76. Melzack R, Coderre TJ, Katz J, Vaccarino AL. Central neuroplasticity and pathological pain. Ann N Y Acad Sci 2001; 933:157-174.

77. Kawakami M, Weinstein JN, Chatani K, Spratt KF, Meller ST, Gebhart GF. Experimental lumbar radiculopathy. Behavioral and histologic changes in a model of radicular pain after spinal nerve root irritation with chromic gut ligatures in the rat. Spine 1994; 19:1795-1802.

78. Manchikanti L, Singh V, Falco FJ, Cash KA, Fellows B. Cervical medial branch blocks for chronic cervical facet joint pain: A randomized double-blind, controlled trial with one-year follow-up. Spine 2008; 33:1813-1820.

79. Manchikanti L, Singh V, Falco FJ, Cash KA, Pampati V. Lumbar facet joint nerve blocks in managing chronic facet joint pain: One-year follow-up of a randomized, double-blind controlled trial: Clinical Trial NCToo355914. Pain Physician 2008; 11:121-132.

8o. Manchikanti L, Singh V, Falco FJE, Cash KA, Pampati V. Effectiveness of thoracic medial branch blocks in managing chronic pain: A preliminary report of a randomized, double-blind controlled trial; Clinical trial NCToo355706. Pain Physician 2008; 11:491-504.

81. Ji RR, Woolf CJ. Neuronal plasticity and signal transduction in nociceptive neurons: Implications for the initiation and maintenance of pathological pain. Neurobiol Dis 2001; 8:1-10.

82. Pasqualucci A. Experimental and clinical studies about the preemptive analgesia with local anesthetics. Possible reasons of the failure. Minerva Anestesiol 1998; 64:445-457.

83. Arner S, Lindblom U, Meyerson BA, Molander $\mathrm{C}$. Prolonged relief of neuralgia after regional anesthetic block. A call for further experimental and systematic clinical studies. Pain 1990; 43:287297.

84. Lavoie PA, Khazen T, Filion PR. Mech- anisms of the inhibition of fast axonal transport by local anesthetics. Neuropharmacology 1989; 28:175-181.

85. Bisby MA. Inhibition of axonal transport in nerves chronically treated with local anesthetics. Exp Neurol 1975; 47:481-489.

86. Cassuto J, Sinclair R, Bonderovic $M$. Anti-inflammatory properties of local anesthetics and their present and potential clinical implications. Acta Anaesthesiol Scand 2006; 50:265-282.

87. Tachihara H, Sekiguchi M, Kikuchi S, Konno S. Do corticosteroids produce additional benefit in nerve root infiltration for lumbar disc herniation. Spine 2008; 33:743-747.

88. Manchikanti L, Cash KA, McManus CD, Pampati V, Smith HS. Preliminary results of randomized, equivalence trial of fluoroscopic caudal epidural injections in managing chronic low back pain: Part 1. Discogenic pain without disc herniation or radiculitis. Pain Physician 2008; 11:785-800.

89. Manchikanti L, Singh V, Cash KA, Pampati V, Damron KS, Boswell MV. Preliminary results of randomized, equivalence trial of fluoroscopic caudal epidural injections in managing chronic low back pain: Part 2. Disc herniation and radiculitis. Pain Physician 2008; 11:801-815.

90. Manchikanti L, Singh V, Cash KA, Pampati V, Datta S. Preliminary results of randomized, equivalence trial of fluoroscopic caudal epidural injections in managing chronic low back pain: Part 3. Post surgery syndrome. Pain Physician 2008; 11:817-831.

91. Manchikanti L, Cash KA, McManus CD, Pampati V, Abdi S. Preliminary results of randomized, equivalence trial of fluoroscopic caudal epidural injections in managing chronic low back pain: Part 4. Spinal stenosis. Pain Physician 2008; 11:833-848.

92. West S, King V, Carey TS, Lohr KN, McKoy N, Sutton SF, Lux L. Systems to Rate the Strength of Scientific Evidence, Evidence Report, Technology Assessment No. 47. AHRQ Publication No. 02E016. Rockville, MD: Agency for Healthcare Research and Quality, 2002. www. thecre.com/pdf/ahrq-system-strength. pdf

93. Atluri S, Datta S, Falco FJ, Lee M. Systematic review of diagnostic utility and therapeutic effectiveness of thoracic facet joint interventions. Pain Physi- 
cian 2008; 11:611-629.

94. Buenaventura R, Datta S, Abdi S, Smith HS. Systematic review of therapeutic lumbar transforaminal epidural steroid injections. Pain Physician 2009; 12:233-251.

95. Benyamin R, Singh V, Parr AT, Conn A, Diwan S, Abdi S. Systematic review of the effectiveness of cervical epidurals in the management of chronic neck pain. Pain Physician 2009; 12:137-157.

96. Conn A, Buenaventura RM, Datta S, Abdi S, Diwan S. Systematic review of caudal epidural injections in the management of chronic low back pain. Pain Physician 2009; 12:109-135.

97. Helm S, Hayek S, Benyamin R, Manchikanti L. Systematic review of the effectiveness of thermal annular procedures in treating discogenic low back pain. Pain Physician 2009; 12:207-232.

98. Salaffi F, Stancati A, Silvestri CA, Ciapetti A, Grassi W. Minimal clinically important changes in chronic musculoskeletal pain intensity measured on a numerical rating scale. Eur J Pain 2004; 8:283-291.

99. Bombardier C. Outcome assessments in the evaluation of treatment of spinal disorders: Summary and general recommendations. Spine 2000; 25:31003103.

100. van Tulder $M$, Furlan A, Bombardier C, Bouter L, Editorial Board of the Cochrane Collaboration Back Review Group. Updated method guidelines for systematic reviews in the Cochrane Collaboration Back Review Group. Spine 2003; 28:1290-1299.

101. Manchikanti L. Evidence-based medicine, systematic reviews, and guidelines in interventional pain management: Part 1: Introduction and general considerations. Pain Physician 2008; 11:161-186.

102. Manchikanti L, Hirsch JA, Smith HS. Evidence-based medicine, systematic reviews, and guidelines in interventional pain management: Part 2: Randomized controlled trials. Pain Physician 2008; 11:717-773.

103. Manchikanti L, Smith HS, Hirsch JA. Evidence-based medicine, systematic reviews, and guidelines in interventional pain management: Part 3: Observational studies. Pain Physician 2009; 12:35-72.

104. Manchikanti L, Smith HS, Hirsch JA. Evidence-based medicine, systematic re- views, and guidelines in interventional pain management: Part 4: Observational studies. Pain Physician; 12:77112.

105. Berg AO, Allan JD. Introducing the third U.S. Preventive Services Task Force. Am J Prev Med 2001; 20:21-35.

106. Guyatt G, Gutterman D, Baumann MH, Addrizzo-Harris D, Hylek EM, Phillips $B$, Raskob G, Lewis SZ, Schünemann $\mathrm{H}$. Grading strength of recommendations and quality of evidence in clinical guidelines. Report from an American College of Chest Physicians Task Force. Chest 2006; 129:174-181.

107. McGregor AH, Anjarwalla NK, Stambach $\mathrm{T}$. Does the method of injection alter the outcome of epidural injections? J Spinal Disord 2001; 14:507-510.

108. Carette S, Leclaire R, Marcoux S, Morin F, Blaise GA, St-Pierre A, Truchon R, Parent F, Levesque J, Bergeron V, Montminy $P$, Blanchette $C$. Epidural corticosteroid injections for sciatica due to herniated nucleus pulposus. $N$ Engl J Med 1997; 336:1634-1640.

109. Snoek W, Weber H, Jorgensen B. Double-blind evaluation of extradural methylprednisolone for herniated lumbar disc. Acta Orthop Scand 1977; 48:635-641.

110. Cuckler JM, Bernini PA, Wiesel SW, Booth RE Jr, Rothman RH, Pickens GT. The use of epidural steroid in the treatment of radicular pain. J Bone Joint Surg 1985; 67:63-66.

111. Dilke TF, Burry HC, Grahame R. Extradural corticosteroid injection in the management of lumbar nerve root compression. Br Med J 1973; 2:635-637.

112. Serrao JM, Marks RL, Morley SJ, Goodchild CS. Intrathecal midazolam for the treatment of chronic mechanical low back pain: A controlled comparison with epidural steroid in a pilot study. Pain 1992; 48:5-12.

113. Klenerman L, Greenwood R, Davenport HT, White DC, Peskett S. Lumbar epidural injections in the treatment of sciatica. Br J Rheumatol 1984; 23:35-38.

114. Rocco AG, Frank E, Kaul AF, Lipson SJ, Gallo JP. Epidural steroids, epidural morphine and epidural steroids combined with morphine in the treatment of post-laminectomy syndrome. Pain 1989; 36:297-303.

115. Ridley MG, Kingsley GH, Gibson T, Grahame R. Outpatient lumbar epidural corticosteroid injection in the management of sciatica. Br J Rheumatol 1988;
27:295-299.

116. Rogers P, Nash T, Schiller D, Norman J. Epidural steroids for sciatica. Pain Clinic 1992; 5:67-72.

117. Hernandez R, Lopez F. Assessment of pain intensity in patients with diabetic polyneuropathy treated with peridural $2 \%$ lidocaine methylprednisolone acetate vs peridural $2 \%$ lidocaine. Anestesia en Mexico 1999; 11:65-69.

118. Kikuchi A, Kotani N, Sato T, Takamura K, Sakai I, Matsuki A. Comparative therapeutic evaluation of intrathecal versus epidural methylprednisolone for long-term analgesia in patients with intractable postherpetic neuralgia. Reg Anesth Pain Med 1999; 24:287-293.

119. Helliwell M, Robertson JC, Ellia RM. Outpatient treatment of low back pain and sciatica by a single extradural corticosteroid injection. $\mathrm{Br} / \mathrm{Clin}$ Pract 1985; 39:228-231.

120. Buchner M, Zeifang F, Brocai DR, Schiltenwolf M. Epidural corticosteroid injection in the conservative management of sciatica. Clin Orth Rel Res 2000; 375:149-156.

121. Valat JP, Giraudeau B, Rozenberg S, Goupille P, Bourgeois P, Micheau-Beaugendre V, Soubrier M, Richard S, Thomas E. Epidural corticosteroid injections for sciatica: A randomised, double blind, controlled clinical trial. Ann Rheum Dis 2003; 62:639-43.

122. Kraemer J, Ludwig J, Bickert U, Owczarek V, Traupe M. Lumbar epidural perineural injection: A new technique. Eur Spine J 1997; 6:357-361.

123. Pirbudak L, Karakurum G Oner U, Gulec A, Karadasli H. Epidural corticosteroid injection and amitriptyline for the treatment of chronic low back pain associated with radiculopathy. Pain Clinic 2003; 15:247-253.

124. Bronfort G, Evans RL, Maiers M, Anderson AV. Spinal manipulation, epidural injections, and self-care for sciatica: A pilot study for a randomized clinical trial. J Manipulative Physiol Ther 2004; 278:503-508.

125. Wilson-MacDonald J, Burt G, Griffin D, Glynn C. Epidural steroid injection for nerve root compression: A randomized, controlled trial. J Bone Joint Surg Br 2005; 87-B:352-355.

126. Arden NK, Price C, Reading I, Stubbing J, Hazelgrove J, Dunne C, Michel M, Rogers P, Cooper C, WEST Study Group. A multicentre randomized controlled trial of epidural corticosteroid injections for 
sciatica: The WEST study. Rheumatology (Oxford) 2005; 44:1399-1406.

127. Andersen KH, Mosdal C. Epidural application of corticosteroids in low back pain and sciatica. Acta Neurochir 1987; 87:52-53.

128. Warfield CA, Crews DA. Epidural steroid injection as a predictor of surgical outcome. Surg Gyn Obstet 1987; 164:457458.

129. Fukusaki M, Kobayashi I, Hara T, Sumikawa K. Symptoms of spinal stenosis do not improve after epidural steroid injection. Clin J Pain 1998; 14:148-151.

130. Stav A, Ovadia L, Landau M, Weksler N, Berman $M$. Epidural steroid injection in the treatment of lumbar and cervical pain syndromes: A preliminary retrospective comparison. Pain Clinic 1991; 4:95-112.

131. Berman AT, Garbarino JL Jr, Fisher SM, Bosacco SJ. The effects of epidural injection of local anesthetics and corticosteroids in patients with lumbosciatic pain. Clin Orthop 1984; 188:144-151.

132. Hickey RF. Outpatient epidural steroid injections for low back pain and lumbosacral radiculopathy. NZ Med J 1987; 100:54-59.

133. Heyse-Moore GH. A rational approach to the use of epidural medication in the treatment of sciatic pain. Acta Orthop Scand 1978; 49:366-370.

134. Harley C. Extradural corticosteroid infiltration: A follow-up study of 50 cases. Ann Phy Med 1966; 9:22-28.

135. Sharma S, Stedman R. Epidural steroids: A retrospective analysis of the efficacy of high and low dose therapy. Anesthesiology 1998; 3A:A1135.

136. Rosen CD, Kahanovitz N, Bernstein R, Viola $\mathrm{K}$. A retrospective analysis of the efficacy of epidural steroid injections. Clin Orthop 1988; 228:270-272.

137. Jamison RN, VadeBoncouer T, Ferrante FM. Low back pain patients unresponsive to an epidural steroid injection: Identifying predictive factors. Clin J Pain 1991; 7:311-317.

138. Hopwood MB, Abram SE. Factors associated with failure of lumbar epidural steroids. Reg Anesth 1993; 18:238243

139. Reale C, Turkiewicz AM, Reale CA, Stabile S, Borgonuovo P, Apponi F. Epidural steroids as a pharmacological approach. Clin Exp Rheumatol 2000; 18: S65-S66.

140. Ito R. The treatment of low back pain and sciatica with epidural corticosteroids injection and its pathophysiologic basis. J Jpn Orthop Assoc 1971; 45:769-777.

141. Bowman SJ, Wedderburn L, Whaley A, Grahame R, Newman S. Outcome assessment after epidural corticosteroid injection for low back pain and sciatica. Spine 1993; 18:1345-1350.

142. Brown FW. Management of discogenic pain using epidural and intrathecal steroids. Clin Orthop 1977; 129:72-78.

143. Warr AC, Wilkinson JA, Burn JM, Langdon L. Chronic lumbosciatic syndrome treated by epidural injection and manipulation. Practitioner 1977; 209:5359.

144. Papagelopoulos PJ, Petrou HG, Triantafyllidis PG, Vlamis JA, Psomas-Pasalis M, Korres DS, Stamos KG. Treatment of lumbosacral radicular pain with epidural steroid injections. Orthopedics 2001; 24:145-149.

145. Silva J, Costa AO, Simoes MT, Neto RR. Management of radicular pain from lumbar herniated disc using betamethasone epidural injection. Revista Brasileira de Ortopedia 1999; 34:165168.

146. Wang JC, Lin E, Brodke DS, Youssef JA. Epidural injections for the treatment of symptomatic lumbar herniated discs. I Spinal Disord Tech 2002; 15:269-272.

147. White AH, Derby R, Wynne G. Epidural injections for the diagnosis and treatment of low-back pain. Spine 1980; 5:78-86.

148. Butterman GR. The effect of spinal steroid injections for degenerative disc disease. Spine J 2004; 4:495-505.

149. Schaufele MK, Hatch L, Jones W. Interlaminar versus transforaminal epidural injections for the treatment of symptomatic lumbar intervertebral disc herniations. Pain Physician 2006; 9:361 366.

150. Campbell MJ, Carreon LY, Glassman SD, McGinnis MD, Elmlinger BS. Correlation of spinal canal dimensions to efficacy of epidural steroid injection in spinal stenosis. J Spinal Disord Tech 2007; 20:168-171.

151. Butterman GR. Treatment of lumbar disc herniation: Epidural steroid injection compared with discectomy. J Bone Joint Surg Am 2004; 86-A:670-679.

152. Butterman GR. Lumbar disc herniation regression after successful epidural steroid injection. J Spinal Disord Tech 2002; 15:469-476
153. Rull BM, Miralles M, Aure S. Therapeutic epidural infiltrations in the lumbar nerve roots. Revista de Ortopedia y Traumatologia 1996; 40:209-217.

154. Caglar S, Erdine S, Aldemir T. The results of the epidural steroid injections in patients with radiculopathies due to lumbar disc herniations. Fizik Tedavi Rehabilitasyon Dergisi 1995; 19:186190.

155. Rivest C, Katz JN, Ferrante FM, Jamison RN. Effects of epidural steroid injection on pain due to lumbar spinal stenosis or herniated discs: A prospective study. Arthritis Care Res 1998; 11:291-297.

156. Koning HM, Koning AJ, Bruinen TCM, Koster HG, Heybroek E. The period of pain relief following a successful epidural steroid injection for low back pain. Pain Clinic 2002; 13:331-338.

157. Manchikanti L, Singh V, Rivera JJ, Pampati V, Beyer CD, Damron KS, Barnhill RC. Effectiveness of caudal epidural injections in discogram positive and negative chronic low back pain. Pain Physician 2002; 5:18-29.

158. Manchikanti L, Pampati V, Rivera JJ, Beyer CD, Damron KS, Barnhill RC. Caudal epidural injections with sarapin steroids in chronic low back pain. Pain Physician 2001; 4:322-335.

159. Riew KD, Park JB, Cho YS, Gilula L, Patel A, Lenke LG, Bridwell KH. Nerve root blocks in the treatment of lumbar radicular pain. A minimum five-year follow-up. J Bone Joint Surg Am 2006; 88:1722-1725.

160. Manchikanti L, Pampati V, Damron KS, McManus CD, Jackson SD, Barnhill RC, Martin JC. A randomized, prospective, double-blind, placebo-controlled evaluation of the effect of sedation on diagnostic validity of cervical facet joint pain. Pain Physician 2004; 7:301-309.

161. Manchikanti L, Manchikanti K, Manchukonda R, Cash KA, Damron KS, Pampati V, McManus CD. Evaluation of lumbar facet joint nerve blocks in the management of chronic low back pain: A preliminary report of a randomized, double-blind controlled trial. Clinical Trial NCTo00355914. Pain Physician 2007; 10:425-440.

162. Manchikanti L, Manchikanti KN, Manchukonda R, Pampati V, Cash KA. Evaluation of therapeutic thoracic medial branch block effectiveness in chronic thoracic pain: A prospective outcome study with minimum 1-year follow up. Pain Physician 2006; 9:97-105. 
163. Fredman B, Nun MB, Zohar E, Iraqi G, Shapiro M, Gepstein R, Jedeikin R. Epidural steroids for treating "failed back surgery syndrome": Is fluoroscopy really necessary? Anesth Analg 1999; 88:367-372.

164. Mehta M, Salmon N. Extradural block. Confirmation of the injection site by $\mathrm{X}$-ray monitoring. Anaesthesia 1985; 40:1009-1012.

165. Burn JM, Guyer PB, Langdon L. The spread of solutions injected into the epidural space: A study using epidurograms in patients with lumbosciatic syndrome. Br J Anaesth 1973; 45:338345.

166. Bartynski WS, Grahovac SZ, Rothfus WE. Incorrect needle position during lumbar epidural steroid administration: Inaccuracy of loss of air pressure resistance and requirement of fluoroscopy and epidurography during needle insertion. Am J Neuroradiol 2005; 26:502-505.

167. Manchikanti L, Bakhit CE, Pakanati RR, Fellows B. Fluoroscopy is medically necessary for the performance of epidural steroids. Anesth Analg 1999; 89:1330-1331.

168. Nishimura N, Khahara T, Kusakabe T. The spread of lidocaine and 1-131 solution in the epidural space. Anesthesiology 1959; 20:785-788.

169. Botwin KP, Natalicchio J, Hanna A. Fluoroscopic guided lumbar interlaminar epidural injections: A prospective evaluation of epidurography contrast patterns and anatomical review of the epidural space. Pain Physician 2004; 7:77-80.

170. Weil L, Frauwirth NH, Amirdelfan K, Grant D, Rosenberg JA. Fluoroscopic analysis of lumbar epidural contrast spread after lumbar interlaminar injection. Arch Phys Med Rehabil 2008; 89:413-416.

171. Manchikanti L, Dunbar EE. Correlation of spinal canal dimensions to efficacy of epidural steroid injection in spinal stenosis. J Spinal Disord Tech 2007; 20:546-547.

172. Barry PJ, Kendall PH. Corticosteroid infiltration of the extradural space. Ann Phys Med 1962; 6:267-273.

173. Fairbank JC, Pynsent PB. The Oswestry Disability Index. Spine 2000; 25:29402952.

174. Deyo RA, Battie M, Beurskens AJ, Bombardier C, Croft P, Koes B, Malmivaara A, Roland M, Von Korff M, Waddell G.
Outcomes measures for low back pain research: A proposal for standardized use. Spine 1998; 23:2003-2013.

175. Fairbank J, Couper J, Davies J, O’Brien JP. The Oswestry low back pain disability questionnaire. Physiotherapy 1980; 66:271-273.

176. Manchikanti L, Pakanati RR, Pampati V. Comparison of three routes of epidural steroid injections in low back pain. Pain Digest 1999; 9:277-285.

177. Price C, Arden N, Coglan L, Rogers P. Cost-effectiveness and safety of epidural steroids in the management of sciatica. Health Technol Assess 2005; 9:158 , iii.

178. Bromage RP, Benumof JL. Paraplegia following intracord injection during attempted epidural anesthesia under general anesthesia. Reg Anesth Pain Med 1998; 23:104-107.

179. Botwin KP. Lumbar interlaminar epidural steroid complications. In: Manchikanti L, Singh V (eds). Interventional Techniques in Chronic Spinal Pain. ASIPP Publishing, Paducah, KY, 2007; pp 355-382.

180. Bilir A, Gulec S. Cauda equina syndrome after epidural steroid injection: A case report. I Manipulative Physiol Ther 2006; 29:492-494.

181. Sabel M, Felsberg J, Neuen-Jacob E, Lichota A, Schnitzler A, Herdmann J. Enlargement of a chronic aseptic lumbar epidural abscess by intraspinal injections $-a$ rare cause of progressive paraparesis. Zentralbl Neurochir 2000; 61:111-114.

182. Parlier-Cuau C, Carlier RY, David P, Silva $M$, Doyon D. Subdural abscess. Rare complication of epidural infiltration: Apropos of a case and review of the literature. J Radiol 1993; 74:205-209.

183. Hooten WM, Mizerak A, Carns PE. Discitis after lumbar epidural corticosteroid injection: A case report and analysis of the case report literature. Pain Med 2006; 7:46-51.

184. Hooten WM, Kinney MO, Huntoon MA. Epidural abscess and meningitis after epidural corticosteroid injection. Mayo Clin Proc 2004; 79:682-686.

185. Hawley JS, Ney JP, Swanberg MM. Subarachnoid pneumocephalus from epidural steroid injection. Headache 2005; 45:247-248.

186. Young WF. Transient blindness after lumbar epidural steroid injection: A case report and literature review. Spine 2002; 27:E476-E477.
187. Browning DJ. Acute retinal necrosis following epidural steroid injections. Am J Ophthalmol 2003; 136:192-194.

188. lida T, Spaide RF, Negrao SG, Carvalho CA, Yannuzzi LA. Central serous chorioretinopathy after epidural corticosteroid injection. Am J Ophthalmol 2001; 132:423-425.

189. Pizzimenti JJ, Daniel KP. Central serous chorioretinopathy after epidural steroids. Pharmacotherapy 2005; 25:11411146.

190. McAllister RK, McDavid AJ, Meyer TA, Bittenbinder TM. Recurrent persistent hiccups after epidural steroid injection and analgesia with bupivacaine. Anesth Analg 2005; 100:1834-1836.

191. Everett CR, Baskin MN, Novoseletsky $D$, Speach D, Patel R. Flushing as a side effect following lumbar transforaminal epidural steroid injection. Pain Physician 2004; 7:427-429.

192. MacLean CA, Bachman DT. Documented arterial gas embolism after spinal epidural injection. Ann Emerg Med 2001; 38:592-595.

193. Mateo E, Lopez-Alarcon MD, Moliner S, Calabuig E, Vivo M, De Andres J, Grau F. Epidural and subarachnoid pneumocephalus after epidural technique. EurJ Anesthesiol 1999; 16:413-417.

194. Katz JA, Lukin R, Bridenbaugh PO, Gunzenhauser L. Subdural intracranial air: An unusual cause of headache after epidural steroid injection. Anesthesiology 1991; 74:615-618.

195. Manchikanti L. Pharmacology of neuraxial steroids. In: Manchikanti L, Singh $\mathrm{V}$ (eds). Interventional Techniques in Chronic Spinal Pain. ASIPP Publishing, Paducah, KY, 2007, pp 167-184.

196. Manchikanti L. Role of neuraxial steroids in interventional pain management. Pain Physician 2002; 5:182-199.

197. Nelson DA, Landau WM. Intraspinal steroids: History, efficacy, accidentality, and controversy with review of United States Food and Drug Administration reports. J Neurol Neurosurg Psychiatry 2001; 70:433-443.

198. Fogel GR, Cunningham PY 3rd, Esses SI. Spinal epidural lipomatosis: Case reports, literature review and metaanalysis. Spine J 2005; 5:202-211.

199. Manchikanti L, Pampati V, Beyer CD, Damron KS, Cash KA, Moss TL. The effect of neuraxial steroids on weight and bone mass density: A prospective evaluation. Pain Physician 2000; 3:357366. 
200. Brill S, Swartz A, Brill G. Epidural steroid injections do not induce weight gain. Curr Drug Saf 2007; 2:113-116.

201. Manchikanti L, Cash KA, Moss TL, Pampati V. Effectiveness of protective measures in reducing risk of radiation exposure in interventional pain management: A prospective evaluation. Pain Physician 2003; 6:301-305.

202. Manchikanti L, Cash KA, Moss TL, Rivera JJ, Pampati V. Risk of whole body radiation exposure and protective measures in fluoroscopically guided interventional techniques: A prospective evaluation. BMC Anesthesiol 2003; 3:2.
203. Manchikanti L, Cash KA, Moss TL, Pampati V. Radiation exposure to the physician in interventional pain management. Pain Physician 2002; 5:385-393.

204. Zhou Y, Singh N, Abdi S, Wu J, Crawford J, Furgang FA. Fluoroscopy radiation safety for spine interventional pain procedures in university teaching hospitals. Pain Physician 2005; 8:49-53.

205. Stav A, Ovadia L, Sternberg A, Kaadan M, Weksler N. Cervical epidural steroid injection for cervicobrachialgia. Acta Anaesthesiol Scand 1993; 37:562-566.

206. Castagnera L, Maurette P, Pointillart V,
Vital JM, Erny P, Senegas J. Long term results of cervical epidural steroid injection with and without morphine in chronic cervical radicular pain. Pain 1994; 58:239-243.

207. Manchikanti L, Boswell MV, Giordano J, Kaplan E. Assessment: Use of epidural steroid injections to treat radicular lumbosacral pain: Report of the Therapeutics and Technology Assessment Subcommittee of the American Academy of Neurology. Neurology 2007; 69:1190. 